Article

\title{
Religious Values in Liberal Democracy
}

\author{
Emily R. Gill
}

Derpartment of Political Science Emerita, Bradley University, 1501 W Bradley Ave, Peoria, IL 61625, USA; gill@fsmail.bradley.edu

Received: 24 October 2020; Accepted: 14 December 2020; Published: 19 December 2020

\begin{abstract}
Religious values neither wholly threaten nor wholly reinforce the stability of liberal democracy. This depends upon how they may be interpreted and applied. The recent influence of Christian nationalists, who would promote a specific interpretation of Christianity as the only legitimate basis for public policy, and of those who would elevate religious liberty above all other rights, does not promote pluralism. Although people should be able to live out their religious commitments, it is the state, not individuals or private organizations, that must draw the line between the free exercise of religion and the civil rights of those who may be adversely affected by the religious exercise of others. First, religious rights may threaten other rights, particularly when reinforced with public funds. Second, religion makes valuable contributions to pluralism when it protects the conscientious beliefs and practices of individuals and of minority religious groups. Finally, concerning LGBT civil rights, individual religious believers should be accommodated as much as possible, but their organizations should be required to arrange for others without objections to provide services that are sought. Religion's greatest contribution occurs when it is allied with movements that enhance individual rights, including but not limited to the free exercise of religion.
\end{abstract}

Keywords: religious freedom; religious liberty; pluralism; Christian nationalism; freedom of conscience; alternatives; public funding; jurisdictional autonomy; John Locke; LGBT civil rights

Religious values neither wholly threaten nor wholly reinforce the stability of liberal democracy. What matters is how they may be interpreted and applied in particular contexts. Distinctions drawn two decades ago by Nancy Rosenblum apply today as much or perhaps more than originally. Moral integralists, she explained, want to use religious values to reinvigorate faith and thereby promote the public good. Civic integralists aim to reinforce democratic values by promoting greater pluralism. Neither of these groups threatens the free exercise of others' beliefs and practices. Foundationalist integralism, on the other hand, seeks "a share of political as well as social power; its goal is to give religion a controlling place in public arenas and public law", seeming to hold that "because of its truths, religion is the sole carrier of value" (Rosenblum 2000, p. 20, see pp. 15-20). The most challenging version, fundamentalist integralism, seeks to apply religious law and authority to every aspect of life, characterizes secular democracy as nihilistic, "conflates discipleship and citizenship," and entails an outright rejection of voluntarism and separationism (p. 15). Citizens of this persuasion are likely to argue that delegitimizing some of the claims of others is a necessary extension of their free exercise of religion.

These distinctions encompass a panoply of views about the proper role of religion in liberal democracy. Although pluralism should function as a core value, without limits a liberal democratic polity would be unable to put forward and adhere to core values of its own in the formulation of public policy. Even a liberal state must be at least minimally committed to some values over others (Galston 1991, pp. 93-97). According to "the logic of congruence," however, some argue that the health of liberal democracy requires voluntary associations to reflect democratic principles in their own organizations and internal life (Rosenblum 1998, pp. 26-41). Individuals, however, should be free to form private associations and enterprises rooted in common purposes without a requirement that 
these entities reflect public values in every particular. The issue here is where to draw the line between the commitments of religious or private organizations and those of the liberal democratic polity when these commitments conflict.

People should be accorded the freedom to live out their religious commitments. I argue here, however, that it is the state, not individuals or private organizations, that must draw the line between the free exercise of religion and the civil rights of those who may be adversely affected by the religious exercise of others. I am particularly though not exclusively attentive to the conflict between defenders of religious freedom and supporters of LGBT civil rights. After establishing some parameters for this conflict, I shall first discuss religious exercise as a possible threat to other rights, especially when reinforced with public funds. Next, I shall discuss ways in which the protection of religious belief and the practices that flow from it contribute to pluralism in liberal democracy. In some circumstances, religious exercise can be protected without specific exemptions, but instead through general policies that protect conscience more generally.

Finally, I shall discuss specific measures that may protect individuals with conscientious objections as well as the greater challenge of balancing religious freedom and LGBT civil rights in collective settings. In many circumstances, we should accommodate individual religious believers, but the organizations to which they belong or the entities where they work should be required to provide the services that are sought by arranging for those without objections to do so. Throughout, I focus upon the importance of alternatives, whether concerning social services, access to reproductive health care, commercial services in connection with marriage equality, or marriage licenses. The rights of individuals, whether to follow their consciences or to secure the civil rights to which they are entitled, must take precedence over those of groups if the promises of liberal democracy are to be fulfilled.

\section{Setting Up the Conflict}

Thomas Berg has argued that religious freedom cannot properly be defended simply as a social contribution to be protected as a matter of policy when it contributes to the common good. This formulation leaves too much to governmental discretion. Rather, the right to religious freedom as a general principle "protects free exercise of religion of all kinds (subject to appropriate limits)" (Berg 2019, p. 309). Moreover, the free exercise of religion preserves personal autonomy and reinforces limits on government. Most important, suggests Berg, is the role of religious organizations as vehicles for the development in citizens of civic virtue, or a regard for the well-being of others. This quality and the activities that flow from it only emerge when religious activities are voluntary, which in turn depends upon the ability of religious organizations and individuals to maintain their religious identities as they envision them. This formulation comports well in many ways with both Rosenblum's moral and civic integralism.

Berg also acknowledges that some activities rooted in religious belief and the practices that flow from them can harm the interests of others. He suggests, however, that this fact does not negate the positive role of religion. "The empirical dynamics of faith-based services give reason to protect even activities that affect others' legal rights" (Berg 321). Even if nonmembers served by religious organizations are adversely affected, "we should not refuse protection simply because the activity affects nonmembers in a way that contravenes a law ... Harms to third parties are relevant, but they are not conclusive" (p. 323; see also pp. 321-25). As long as people are made aware of the policies of religious organizations and there are alternative sources of social services, concludes Berg, religious organizations should not be forced to violate their religious identities.

The distinction between religious belief and practice is a time-honored juxtaposition. In Reynolds $v$. United States, the Supreme Court disallowed the Church of Jesus Christ of Latter-day Saints justification for plural marriage, ruling that to create exemptions from general laws would be to elevate religious belief above civil law "and in effect to permit every citizen to become a law unto himself" (Reynolds v. United States (1879, p. 167; Employment Division v. Smith (1990)). "This division into belief and action," however, "encroaches on something at the core of a human being-to limit worldview to 
expression only of deeply held beliefs without ensuing actions is to strike at the heart of one's own personhood" (Hollinger 2019, pp. 57-60). Although Hollinger writes from a religious perspective, the point also applies to broader instances of conscientious belief. Many people opposed to marriage equality for LGBT couples, for example, maintained that they possessed no objection to the status of those who experienced same-sex attraction; they only opposed the conduct of those desiring to marry their same-sex partners, a point now made by some of those who wish to be exempted from providing goods and services for same-sex weddings. Only same-sex couples, however, desire to engage in the conduct of marrying their same-sex partners; conduct flows from status. Moreover, couples who wish to marry, whether gay or straight, may do so on the basis of conscientious beliefs that they ought to marry (Gill 2012, pp. 145-209; 2019, pp. 168-91). The importance of both beliefs and the practices that flow from them, therefore, apply equally to defenders of religious freedom and of LGBT civil rights. The contributions of both religion and broader conscientious belief to pluralism in a liberal democracy, however, depend upon how this balance is handled.

For Katherine Stewart, powerful segments of the conservative religious community currently seek to promote not pluralism, but rather a particular interpretation of Christianity rooted in a biblical worldview. This Christian nationalism "purports to derive its legitimacy from its claim to represent a specific identity unique to and representative of the American nation" (Stewart 2019, pp. 3-11). This segment of the religious right, explains Stewart, is a political movement, not simply a social or cultural one. It treats Bible study as political advocacy, arguing that the Bible mandates adherence to right-wing policy positions on deregulation, private property, flat-rate taxation, social welfare programs, male supremacy, and illegal immigration (pp. 48-51). And it treats history not as something to be studied, but instead to be interpreted as a means to its own ends (p. 139). It seeks to identify pastors and congregants who will vote on the basis of biblical values to the extent that it is political beliefs, not religious ones, that signify belonging (p. 90).

Many Christian nationalist principles bear the influence of Rousas Rushdoony, the son of Armenian immigrants who barely escaped the Armenian genocide. Rushdoony adhered to the idea that Christian Armenian culture was lost because Armenians were a minority in a non-Christian culture. For him, there could be no neutral ground. Christians needed to redeem the authentically Christian nation that he believed the Constitution was designed to perpetuate from the godless humanism that was enveloping it. Christian schools, for example, must gain independence from what many conservatives call government schools. This agenda has now been advanced through tax-supported vouchers to be used at private schools and by introducing Christian principles into lightly regulated charter schools (Stewart 2019, pp. 185-86, 193-208, 218-19; 227-33). "Liberal education", Rushdoony lamented, "is inevitably pluralistic" (Stewart 2019, pp. 102-20). Christians need to take back education, law, and civil government to reconstruct a Bible-based order, according to influential conservative thinker Gary North, "which finally denies the religious liberty of the enemies of God" (p. 119).

To this end, under a Freedom for All initiative—formerly titled Project Blitz-conservative Christians have introduced coordinated religious freedom bills into all state legislatures, covering areas such as contraceptive access and freedom to discriminate against targeted groups such as LGBT individuals (Stewart 2019, pp. 152-68). According to Christian nationalists, this agenda will return us to a time revered by dominionists, or those who believe "that right-thinking Christians should assume power in all spheres of life" (pp. 123, 127-28). Legal advocacy groups such as the Alliance Defending Freedom, formerly Alliance Defense Fund, and their allies claim that their intention is only to defend free speech and persecuted Christians. For Stewart, however, the goal seems to be "to allow their version of Christianity, and their understanding of the Bible, to shape law and government" (p. 215), eventuating in "the broader privileging of conservative Christianity in America" (pp. 211, 234-35).

This application of religion and of Christianity in particular does not reinforce the stability of liberal democracy. Although many conservative Christians are not Christian nationalists, Christianity is the majority religion in the United States. Giving one interpretation of Christian religious values a controlling place in the public arena characterizes Rosenblum's foundationalist integralism, not the 
pluralism associated with liberal democracy. And the goal of applying religious authority to every aspect of life, characteristic of Rosenblum's fundamentalist integralism, would surely deny not only religious but many other kinds of liberty to the "enemies of God".

Christian nationalists are correct that there is no neutral ground-if neutrality means evenhandedness among all possible alternatives. Different kinds of neutrality exist in different contexts, because neutrality has meaning only when it can be measured or judged in terms of some independent standard, or one that is agreed upon for the purpose at hand. This point can be illustrated by the difficulty with nonpreferentialism in religious jurisprudence, or the idea that a government that evenhandedly accords benefits to all religious groups is neutral and therefore is not establishing religion. First, true evenhandedness is not only difficult to achieve but is also politically unrealistic when unpopular or minority religious groups are involved. Second, even if evenhandedness among religions exists, nonpreferentialism is not evenhanded between religion and nonreligion. Whereas religious neutrality used to connote separationism-no aid to religion lest the government favor some religions or favor religion in general-in recent years, it has been interpreted as equal access, exemplified by Widmar v. Vincent (1981), in which the Supreme Court ruled that a state university's religious student organizations could not be denied access to a campus building for their meetings when secular student organizations were admitted. No-aid provisions mean that religious entities are denied benefits available to nonreligious entities, meaning that no-aid policies are also nonneutral.

Until recently, the Supreme Court allowed indirect but not direct aid to religious entities. In 2002, it allowed the Cleveland School District to offer vouchers to students in failing schools that could be redeemed in other districts' public schools or in private schools, both religious and nonreligious (Zelman $v$. Simmons-Harris 2002). The establishment clause was not violated not only because the vouchers were directed by parents and did not go directly to religious schools if those were selected, but also because the policy's intent was not specifically to aid religious practice because that practice was religious (Gill 2019, pp. 25-28). “For government aid to religious institutions or individuals to be valid, the religious recipients must be part of a formally neutral class of recipients that includes both religious and nonreligious individuals and institutions." Moreover, "aid that goes directly from the government to the religious recipient ... differs from aid that goes first to some private individual or entity who then chooses to funnel it to a religious recipient" (Wexler 2019, pp. 113-14, emphasis original; see pp. 112-20).

Over time, however, the Supreme Court has been increasingly willing to allow even direct aid to religious schools for nonreligious purposes, basing its judgments on the character of the aid itself, rather than upon whether the institution is "pervasively sectarian" (Lupu and Tuttle 2014, pp. 105-6). In Trinity Lutheran Church v. Comer (2017), the court overturned Missouri's exclusion of a Lutheran church's learning center because of its religious character from a competitive program using recycled tires to resurface school playgrounds, as this public benefit did not finance the direct provision of religious instruction. In 2020, the court relied upon Trinity Lutheran in upholding a Montana program of tax credits for individuals donating money to organizations awarding scholarships for private school tuition, despite the fact that the state constitution barred the use of government funds for any sectarian purpose (Espinoza v. Montana Department of Revenue 2020). Although some of the scholarship funds might serve religious ends, to the court the Montana Supreme Court had applied the no-aid provision based solely upon the religious status of recipient schools, which was a violation of equal access to a publicly available benefit.

The aid in Trinity Lutheran was direct while that in Espinoza was indirect. According to the prevailing model, though, it seems that when religion partakes of public benefits, it may do so because its mission fulfills a secular purpose or social function that accords with public policy, in this case enhancing education. In a dissent in Espinoza, however, Justice Sonia Sotomayor noted, "Until Trinity Lutheran, the right to exercise one's religion did not include a right to have the State pay for that religious practice" (Sotomayor, slip opinion, p. 8). Moreover, the government may pick and choose 
among applicants for benefits, meaning that some religious manifestations will inevitably be favored over others when religious organizations are beneficiaries.

Two difficulties present themselves in this context. The first appeared in the faith-based initiative pursued by President George W. Bush under the charitable choice provisions of the 1996 welfare reform law. This program encouraged states to enter contracts with nongovernmental organizations, both secular and religious, to provide nonreligious social services, such as food banks, soup kitchens, and job training. Excluding religious organizations would have penalized them for being religious. Simultaneously, however, this initiative allowed religious groups to retain their religious character in matters such as displaying religious symbols or using religious criteria in selecting employees. That is, nondiscrimination laws could be set aside, so that religious groups could not only receive secular benefits but also retain religious exemptions. Although these programs appeared to enhance choice, choice may be a casualty of a lack of alternatives, as in an Iowa prison program, InnerChange Freedom Initiative, a rigorous Christian program offering material benefits, more family contact, and help with parole boards as incentives to participate. The only applicant that met state requirements, it called on participants to abandon false religions and taught that homosexuality was sinful. Prisoners had no other access to the program's benefits. Federal courts eventually struck down IFI as a violation of the establishment clause. "Yet ... the state made no religious decisions, acted on the basis of generally applicable laws that were facially religion-neutral, and pursued indisputably valid secular purposes at every stage of the process" (Koppelman 2013, pp. 110-14; Gill 2019, pp. 78-82).

The second difficulty lay in controversy over the recipients of these funds. Most religious recipients had some connection to Christianity-as is also true now of religious schools participating in charter school and voucher programs (Wexler 2019, pp. 109-10, 120-21; Gill 2019, p. 76; Stewart 2019, p. 204). Some states have resisted voucher programs on realizing that Muslim schools as well as Christian ones would be eligible to participate, or when Louisiana adopted one only when a Muslim school withdrew a prior request to participate. One state representative there said, "I actually support funding for teaching the fundamentals of America's Founding Fathers' religion, which is Christianity, in public schools or private schools [but] we need to insure that that it does not open the door to fund radical Islam schools" (Wexler 2019, pp. 110-11). Some Christians will forego money rather than award it to minority religions (p. 121).

They may also reject the idea that these religions might claim equal rights under the law (Stewart 2019, p. 158) even when money is not at issue. For example, after the Supreme Court extended its Widmar mandate opening public universities to religious student organizations to public schools as well (Good News Club v Milford Central School 2001), Christians used various means to exclude Wiccans, atheists, Muslims, and other minority religions from the schools (Stewart 2019, pp. 224-25; Wexler 2019, pp, 147-55). The Good News Club seeks to bring the Gospel to children in after-school meetings complete with memorized Bible verses and stories, songs, games, prayers, and treats. Although students may attend only with parental permission, leaders seem pleased that many think the clubs are school-sponsored groups, and children get prizes if they recruit friends to seek their parents' permission to join (Wexler 2019, pp. 140-46). In short, whether we are discussing religious symbols in the public square, social service programs, school vouchers, or after-school clubs, Christianity will predominate overall. Although policies may be formally neutral and without an intention of favoring Christianity, the resulting effects cannot help but favor the dominant religion to the exclusion of other belief systems—even without the help of Christian nationalists.

\section{The Current Religious Threat to Pluralism}

Any culture will of course reflect elements of the groups and interests that predominate within it. The problem is striking a balance between the ability of individuals and groups to engage in the practices that flow from their religious faiths, on the one hand, and the ability of those with opposing beliefs, religious or not, to live out the practices that flow from their own commitments. This tension is acute when some interpret the practice of religious beliefs as requiring a context that permeates the 
whole of life. "If, to be fully effective, a religious doctrine requires control over the totality of individual life, including the formative social and political environment, then the classic liberal demand that religion be practiced privately amounts to a substantive restriction on the free exercise of religion" (Galston 1991, p. 277). Although a liberal society is pluralistic, the range of its pluralism excludes some kinds of groups; and "for those who are left out, it is hard to see how liberalism can be experienced as anything other than an assault" (pp. 143-49).

William Galston is here referring primarily to minority religious groups. In this context, we tend to think of the Old Order Amish and Jehovah's Witnesses, or of other groups, some of whom are conservative Christians, whose practices may run afoul of generally applicable laws. If the practice of religious belief-or of any belief system-requires control over the whole of life, this demand may work in voluntary communities that sequester themselves from the larger society. It is not compatible, however, with a liberal society and state, in which individuals expect the freedom within broad limits to order their lives as they see fit. Although discussion is beyond the scope of this article, it is one thing for a liberal democracy to accord freedom to these groups-perhaps foundationalist or fundamentalist integralists- to order their communal lives, within limits and absent violence or abuse, as consenting adults within them see fit. It is quite another, however, to apply these principles to the population at large. Many Christian conservatives-and certainly Christian nationalists-desire control over all of life not only for themselves, but also as this pertains to the lives of others as well.

\subsection{The Priority of Religious Liberty?}

In the spring of 2020, the Justice Department hosted a week of training for its lawyers to bolster its increased emphasis upon the protection of religious freedom, which Attorney General William Barr described as "a core American value and a top priority for the department" (Benner 2020). In 2019, Secretary of State Mike Pompeo, an evangelical Christian, created a Commission on Unalienable Rights "to provide a new vision for human rights policy that would more closely align with the 'nation's founding principles' and uphold religious freedom as America's most fundamental value". Supporters deplored what they viewed as the current departure "from our nation's founding principles of natural law and natural rights." Describing the Trump administration's recognition of religious liberty as "our country's first freedom," Pompeo said, "I know where those rights came from. They came from our Lord" (Verma 2020a). On the release of the Commission's report in 2020, Pompeo criticized the New York Times's 1619 Project, based on scholars' reexaminations of the legacy of slavery, as "a dark vision of America's birth" and a "disturbed reading of our history" (Verma 2020b). Former agency officials and human rights scholars have criticized this elevation of religious liberty, however, as a deviation from the United States's longstanding policy that all rights are created equal.

Elevating the protection of religious freedom over other rights potentially allows these other rights to be upheld only insofar as they accord with the religious beliefs of the protectors. Different religions, as well as groups and individuals within the same religious community, vary in their interpretations of their religious commitments. A number of Pompeo's panel members were religious conservatives opposing abortion and marriage equality. Other nations that follow this lead may use religious reasons to deny access to reproductive health services or to persecute LGBT individuals and same-sex couples. Diplomatic efforts to promote women's rights in Iran and Saudi Arabia and to stop the persecution of the Uighur minority in China may come to naught. A hierarchy of rights, opined a former Obama administration official, may bolster repressive governments to say, "We are no different from you. You have your priorities; we have ours. Now butt out" (Verma 2020a, 2020b, 2020c).

Elevating religious liberty as the priority is also problematic on the domestic front. The equal access interpretation of the First Amendment enables religious social service programs and schools to operate on a level playing field with nonreligious ones. Although it contributes to pluralism in terms of eligibility, it can detract from pluralism within entities that it now includes, an important consideration when public funds are involved. The issue of equal access increased in public visibility in recent years, beginning with damages to the east coast in 2012 caused by Hurricane Sandy. After devastating 
hurricanes in 2017 affecting Texas, Florida, and Puerto Rico, the Federal Emergency Management Agency (FEMA) and several members of Congress suggested that aid for repairs should be available to houses of worship. FEMA already offered reimbursements to religious entities for sheltering evacuees, awarded grants to religious schools, health care providers, and nursing homes, and could aid in repairs to church-run community centers-as long as under half the use or the space was for religious purposes. To some, refusing aid for damaged houses of worship whose congregants respond robustly to disaster-related needs in the larger community is patently unfair, while to others, rebuilding houses of worships is the quintessential example of an establishment of religion (Lieb 2017; Green 2018).

The crux of this tension appears at the intersection between the reasons for awarding public funds to religious entities, on the one hand, and what sorts of accountability may follow from this, on the other. Tax exemptions for religious organizations are based upon the idea that taxation would impede the free exercise of religion, not because they provide essential public services. They are therefore exempt from a number of typical requirements (Stewart 2019, pp. 225-26). One can reasonably argue, however, that identifying an institution as a religious rights holder should not entitle it to protected status in all of its activities, as in current exemptions from state licensing of religiously affiliated daycare centers (Lupu and Tuttle 2016, p. 384; Robinson 2016, p. 179). Perhaps "corporate entities with asserted religious identities deserve exceptional treatment only with respect to their distinctively religious activities" (Lupu and Tuttle 2016, pp. 375-76, 381; Gill 2019, pp. 135-42). Even regarding the ministerial exception, courts must often still decide which positions it protects Hosanna-Tabor Evangelical Lutheran Church and School v. EEOC (2012).

For example, pension law allows churches and other affiliated religious organizations to opt out of complicated and costly rules that secular organizations must follow, which most do, especially when an institution encounters financial difficulties. Opting out also means that pension information need not be disclosed to employees, who may learn belatedly that their pensions are disappearing. When the issue of employee protection has arisen in Congress, "lawmakers have expressed confidence that religious employers will handle their pension funds fairly, because ... the religious employers answer to a higher authority" (Walsh 2006, p. C6; James 2019; Stewart 2019, p. 243). Safety regulations for daycare centers and the protection of employee pensions are not distinctively religious issues.

\subsection{Problems with Public Funding}

This issue becomes more prominent when public funds are involved. When Hurricane Harvey battered Houston in 2017, three churches filed suit to force FEMA to provide disaster relief funds to houses of worship. Although churches can buy property insurance, some churches believe that the expense is too great, so they want to rely on the federal government for bail-outs. Although when FEMA aid was first proposed in 2013, the Republican-controlled Senate objected due to the constitutional issues raised. In 2018, however, reactions were muted when FEMA announced that houses of worship were now eligible. Some churches do provide essential services, such as aid to hurricane and flood victims in time of disaster, and often food pantries for the needy on an ongoing basis. "To the extent that they do, and if they should organize those activities with the kind of transparency, fairness, and accountability required of other nonprofits, few would argue with their claim to public money" (Stewart 2019, pp. 226-27). For example, nonprofit social service organizations such as Catholic Charities and Lutheran Social Services, both secular and religious, may receive public funds as separately incorporated nonprofit groups, which forbid proselytization and require compliance with civil rights laws in hiring practices (Formicola 2003, pp. 46-50; Gill 2019, p. 83). Religious nonprofits, however, have not always adhered to these requirements and have increasingly sought exemptions from generally applicable civil rights laws (Gill 2019, pp. 82-98). Public funding, however, should come with public accountability; religious entities should not be able to have it both ways.

One would also hope that churches or other houses of worship receiving disaster aid themselves would serve those they are helping equally, without regard to religion, ethnicity, sexual orientation, or 
gender identity. Two of the three suing churches in Houston in 2017 did not claim to be providing essential services, and all three belonged to the Assemblies of God Pentecostal denomination, whose doctrinal statement condemned the cultural acceptance of "homosexual" identity, marriage equality, and efforts to change one's biological gender as symptoms "of a broader spiritual disorder that threatens the family, the government, and the church." The denomination has also stated that "the spread of oriental ... religions and the occult in America has brought with it an increase in demon possession" (Stewart 2019, p. 226). As Stewart wonders, "Why should taxpayers be on the hook for church facility insurance? Shouldn't 'oriental' and 'homosexual' taxpayers have a say?" (p. 227) Along similar lines not involving public funds, during the spring of 2020 COVID-19 pandemic Samaritan's Purse, the evangelical organization led by the Rev. Franklin Graham, set up a temporary field hospital in Central Park in connection with Mount Sinai Health System. It treated all in need, but Samaritan's Purse required employees to be Christians opposing marriage equality and required even volunteers to sign a statement adhering to this belief (Stack and Fink 2020). As a private organization, Samaritan's Purse may operate as it chooses. If it were receiving public funds, however, legal repercussions might have ensued. That is, the employees of and volunteers with such entities should not be required to affirm their opposition to public values reflected in civil rights laws.

Citing government aid in the form of tax exemptions; fire and police protection; government-financed texts, computers, and remedial education; and school vouchers that citizens may direct to their choice of programs, David Cole states, "The Constitution does not require strict separation of church and state, because in a modern society in which virtually everyone benefits from some form of government support, that would amount to discrimination against religion" (Cole 2001). With more private entities receiving public funds, however, accountability becomes an urgent issue. The disestablishment of religion protects religious matters from government interference and avoids public funding of religion. "Failure to acknowledge that money matters in our religious liberty tradition feeds the damaging all-or-nothing narratives. It emboldens those who would deny all religious exemptions and those who advocate for the broadest religious exemptions to LGBT nondiscrimination laws" (Hollman 2019, p. 299). What some term the sovereigntist approach emphasizes the importance of the collective pursuit of religious values and objectives that would be nearly impossible for individuals alone. "Individual religious conscience makes little sense outside the context of the religious group. It is within that context that individuals' religious consciences are shaped, affirmed, and expressed" (Monsma 1996, pp. 18-21, 163, 174). Groups are central to the formation of individual beliefs and also to the development of religious doctrine. Therefore, they should enjoy great autonomy from regulation (Brady 2004, pp. 1675-79, 1694-95; Helfand 2019, pp. 135-40), with or without the aid of public funds. From an opposing perspective, however, "Failure to appreciate that government funding undercuts claims for autonomy will likely harm our tradition of religious liberty" (Hollman 2019, pp. 303-6).

Advocates of equal access to generally available public benefits, including funding, hold that the autonomy of religious groups protects pluralism, "the right of individuals and institutions to be different, to teach different doctrines, to dissent from dominant cultural norms and to practice what they preach." On the view of Michael McConnell, several 2020 Supreme Court decisions are exemplary in this manner. By allowing the use of tax credits for scholarships applicable at both secular and religious private schools as discussed above, Espinoza v. Montana Departmartment of Revenue (2020) allows school choice to parents whose children might otherwise be trapped in inferior public schools, and it thereby potentially reduces economic and social inequality. By prohibiting government interference in religious schools' choices of those who teach religion classes even when discrimination is claimed, Our Lady of Guadalupe v. Morrissey-Berru (2020) guarantees schools against intrusive claims that religious considerations if a teacher is fired might in fact be pretextual. Finally, Little Sisters of the Poor v. Pennsylvania (2020) allows religious orders to opt out of providing contraceptive coverage to employees in violation of their beliefs (McConnell 2020). 
Each of these cases, however, expands the free exercise of religion in ways that can impinge upon the lives of those who do not share these beliefs. Scholarships and vouchers for religious schools allow greater choice, but public funds can be awarded indirectly to schools teaching that the United States is a Christian nation, that Christianity is the only valid religion, that women should be subservient to men, and that LGBT individuals should not be treated as equal citizens. Guadalupe builds upon the ministerial exception as defined in Hosanna-Tabor in 2012, reinforcing the argument that no matter how few religious duties a teacher might perform, these outweigh any legal protections a fired employee might invoke. An employer may discriminate on the basis of race, age, disability, and other traits unrelated to its religious beliefs and may do so even if the employee does not have a formal title such as that of "called teacher" as in Hosanna-Tabor. The combined effect of Espinoza and Guadalupe, moreover, forces taxpayers to subsidize policies that would be unacceptable in other venues.

The issues in Little Sisters had been litigated for a decade. The Supreme Court in Burwell v. Hobby Lobby Stores (2014) ruled that for-profit corporations not publicly traded may refuse to provide insurance coverage for objectionable contraceptives if doing so would substantially burden their religious practice based on sincerely held religious beliefs. Under Obama administration rules governing the Affordable Care Act of 2010, religious nonprofits were eventually exempted from providing contraceptive insurance by signing a certification that then allowed insurers to provide otherwise for free contraceptive services. The Little Sisters, a religious order serving the elderly poor, and some other groups, however, objected to this notification because signing off would make them complicit in sin. In 2017, President Donald Trump issued rules greatly expanding the rights of employers, religious or not, to decline to provide contraceptive coverage without notification on the basis of either sincerely held religious beliefs or general moral convictions (Pear and Ruiz 2017, p. A14; Gill 2019, pp. 89-91, 164-65), exceeding the claims of both religious nonprofits and of closely held corporations. Little Sisters plus a related 2020 case, Trump v. Pennsylvania (2020), confirmed these rules.

\subsection{The Importance of Alternatives}

A key issue in all of these subject areas is the existence of alternatives. Bush's faith-based initiative aimed at providing not only greater inclusivity for social service providers, but also greater choice for clients. In 2010, President Barack Obama signed an executive order stipulating explicitly that beneficiaries be referred to alternative providers if they objected to the religious character of a potential or actual provider, and also that providers notify beneficiaries that they may request these referrals. In 2018, however, the Trump administration issued an executive order striking both the referral and the notification requirements, arguing that they burdened religious social service providers and were therefore discriminatory. This objection could be avoided if the administration simply extended the rule to all social service providers, nonreligious as well as religious (Marcus 2020; Rogers 2019, pp. 108-12). The administration also proposed alerting faith-based organizations that they could apply for unspecified additional religious exemptions from existing federal regulations. For example, a Jewish person might have to accept mental health counseling from a conservative Christian provider, or a homeless gay teen might have to obtain assistance from an anti-LGBT faith-based shelter (Hayes 2020).

Keeping citizens in ignorance of alternatives is not new. In Rust v. Sullian (1991), the Supreme Court upheld public funding for a family planning program that was contingent on private social service providers' silence about abortion as an option, ruling that "the government can, without violating the Constitution, selectively fund a program to encourage certain activities it believes to be in the public interest, without at the same time funding an alternative program that seeks to deal with the problem another way" (Rust v. Sullivan 1991, p. 193). Because public funds were involved, the government was entitled to express its own values and viewpoint. Much opposition to abortion is religiously based, however. Publicly funded programs should not promote ignorance. Similarly, in 2018 the Trump administration issued rules forbidding family planning programs such as Planned Parenthood from providing referrals to doctors who can perform abortions on penalty of losing funding under Title $\mathrm{X}$, although the vast majority of this money has covered health screenings, contraception, 
and pregnancy tests. The administration has shifted its emphasis to conservative teen pregnancy prevention programs that promote abstinence and to religious exemptions for employers who object to insurance coverage for birth control (Belluck 2019). The referral issue is still in contention, with the Ninth Circuit Court of Appeals upholding the restrictions while the Fourth Circuit temporarily blocked them - though this was effective only in Maryland (Politico 2019).

Problems with alternatives also emerge from the 2020 Supreme Court decisions described above. Public funding for vouchers or scholarships as in Espinoza promote choice on one level, but can narrow the exposure of students to the full range of the legitimate diversity characteristic of a liberal democracy. Autonomy for religious schools as in Guadalupe may promote diversity among educational institutions, but it leaves employees with little recourse in the face of what may be legitimate grievances. Little Sisters as well as the earlier Hobby Lobby decision allow employers their free exercise of religion, but at the expense of employees who often do not share those beliefs. It is here that burdens on third parties may be severe (Gill 2019, pp. 158-68).

One way of approaching third-party impacts is to distinguish between religious exemptions that directly affect only religious practitioners, such as ritual observances or dress, and those that affect others who do not share the beliefs of the claimants, such as contraception for employees, abortion care, or commercial services connected with same-sex weddings. Some individuals and organizations want exemptions not only from the provision of goods or services to which they have conscientious objections, but also from providing counseling and referrals to alternative providers to avoid complicity in activities they view as sinful. The new rules mentioned above, which exempt employers with either religious or moral objections from providing contraceptive coverage, also exempt them from government scrutiny and from any obligation to notify employees (NeJaime and Siegel 2019, pp. 70-79; Melling 2019, pp. 250-52; Rogers 2019, p. 164). Sincere conscientious objections to military service may be either religious or moral, of course, but these exemptions do not impose direct burdens on third parties.

One response to these difficulties can be found in what some term implied consent institutionalism. Joining or affiliating oneself with a religious entity implies consent to the rules entailed in its self-governance, including its methods for resolving internal disputes. Otherwise an institution's pursuit of its collective religious objectives may be seriously impeded. The question then shifts from the number of religious responsibilities triggering the ministerial exception, as in Hosanna-Tabor and Guadalupe, to the expectations of the member or employee. It "focuses on whether the context justifies an inference of implied consent to the authority of the institution and not the religious nature of the organization or [even] whether it is operated for profit" (Helfand 2019, pp. 137-44). This in turn means that an institution must clearly convey its expectations at the outset.

Complications arise, however, when employees may be indifferent to the religious nature or commitments of an institution but simply accept available jobs in their fields of expertise, or when employers formulate policies in response to changes in the law, as with Hobby Lobby's objection to certain contraceptives in the wake of administrative rules concerning the Affordable Care Act. Employees may consent to religious rules or a dispute resolution process in general, but they cannot foresee the substance of particular issues until they arise (Helfand 2019, pp. 145-49). Moreover, because contraceptive coverage is mandated in the law, it may not even occur to either potential or actual employees that their employers' commitments could affect these benefits. And the response that those who object should simply seek employment elsewhere is not necessarily realistic. Related issues may arise in the context of religiously affiliated colleges and universities, where both employees and students should be given detailed notice of these institutions' expectations when they affiliate with them (Hill 2019; Hoogstra et al. 2019). Schools and institutions of higher learning, however, that receive public funds should enjoy less religious autonomy than those that do not, although this subject is beyond the scope of this article. 


\subsection{Exit Rights as Jurisdictional Autonomy}

The autonomy of religious groups or of secular institutions with religious commitments protects pluralism and allows both groups and individuals to pursue values that differ from cultural norms, as McConnell notes (McConnell 2020). Nevertheless, exempting entities, religious or not, from generally applicable laws that serve our shared societal commitments creates "'rights to exit' civil society and the social compact at its core, or at least, rights to exit some substantial part of it" (West 2016, pp. 403-7). Civil rights enhance individual liberty through rights to enter civil society through speech, voting, equal protection, and so forth. They expand and deepen individual rights to participate in society on the same basis as others. Exit rights, however, enhance individual liberty by allowing rights holders to refuse to participate in some of the shared projects that constitute civil society. Although some exit rights are attractive, such as parents' rights over their children's schooling or women's rights over their bodies, they nevertheless create "separate sovereignties ... protecting the rights of some to exercise authority over the interests and rights of others, free of state dictates to the contrary" (pp. 409-413). More specifically, exit rights are "about opting out." For example, "Hobby Lobby takes the unprecedented step of exempting business corporations from an employee-protective law in the name of the religious liberty of shareholders" (Pollman 2016, p. 170).

Although the logic of congruence, or the idea that all voluntary associations should reflect liberal democratic principles in their organization and internal life, would dampen pluralism, limits should apply. For example, Boy Scouts of America v. Dale (530 U.S. 640 [2000]), in which the Supreme Court allowed the Scouts to expel an openly gay scoutmaster on grounds of associational freedom of expression, was correctly decided. In a liberal polity, like-minded individuals should be able to associate to express and practice their beliefs in privately funded organizations, religious or nonreligious, without being forced to accept or retain those who disagree. The latter may leave and form new organizations, but with a major qualification: other alternatives or opportunities must be available without imposing an undue burden upon those who are rejected or who leave. When issues such as possible wrongful termination of employment or limitations on health care mandated by law are at stake, a closer look may be required.

According to John Locke, although a religious body may expel individuals at odds with its principles, "No private person has any right, in any manner, to prejudice another person in his Civil Enjoyments, because he is of another Church or Religion. All the Rights and Franchises that belong to him as a Man, or as a Denison [denizen], are inviolably to be preserved to him. These are not the Business of Religion" (Locke [1689] 1983, pp. 26-28, 31). On the one hand, Locke was defending the freedom of the like-minded to associate without threat from those who might alter these principles and corresponding message through their membership. On the other hand, he was also indirectly addressing the importance of maintaining a forum that provides alternative opportunities. Sometimes a society maintains such opportunities spontaneously; at other times, these must be offered or maintained by public authority through laws.

Although the state in a liberal democracy must be neutral about religious truth, it cannot be neutral about where to draw the line between the civil and the religious. That is, it must have "meta-jurisdictional sovereignty" even when it defers to other authorities in some areas (Laborde 2017, p. 162; Gill 2019, pp. 31-48). Private voluntary associations, religious and nonreligious, possess unique expertise in interpreting their purposes and commitments and in applying them to their practices. Therefore, they should be accorded jurisdictional autonomy in line with this competence, although not complete immunity when nonreligious interests may be at stake. What they do not possess is "competence interests to identify their own area of competence ... they do not have a right to jurisdictional self-definition" (Laborde 2017, pp. 190-96; Gill 2019, pp. 46-48). Only liberal democratic states with final authority "represent the interests of individuals qua individuals, regardless of their contingent features, identities, and memberships" (Laborde 2017, p. 162, emphasis original; see pp. 160-70). In many areas, Christian nationalists and their supporters would accord jurisdictional 
self-definition to the religious groups of the United States's majority religion, Christianity, with serious consequences for pluralism.

\section{Current Religious Contributions to Pluralism}

Many secularists and atheists maintain that the world would be better off without religion. Some would substitute a scientific epistemology for religion, implying that ordinary religious people "are gullible dupes who have failed to exhibit the necessary reasoning power to arrive at atheism and an 'enlightened' morality" (LeDrew 2020, p. 421). The implication is that moral autonomy will be encouraged by this more neutral mindset. Stephen LeDrew, an atheist himself, notes, however, that individuals are socialized into value systems other than religion, such as scientism, capitalism, and even liberalism. "Perhaps religion is not the best basis for social solidarity, but nothing yet has come to take its place" in a world characterized by economic, social, and racial inequality as well as the rise of religious "nones" (Jones 2016, p. 422; see p. 226).

Individuals and groups on both sides of the controversy over religious values agree that pluralism and diversity contribute to the stability of liberal democracy. They disagree, however, about what this means and how it may be achieved. Where some would accord jurisdictional autonomy to collective entities, particularly religious ones, others would prioritize individuals and their rights and liberties as equal citizens. The difficulty lies in the fact that no neutral ground exists. Liberal democracy allows choice within a range of preferences, which are entailed by its core commitments. But it cannot allow choice among all conceivable preferences. First, its espousal of core commitments acts to produce one range of preferences and not others. Second, disagreement abounds as to what even these core commitments should be (Gill 2001, pp. 2-4, 30-33; Neal 1997, pp. 34-47). Therefore, pluralism's defenders must be explicit as to what version of pluralism they have in mind.

I subscribe to what Cécile Laborde terms minimal secularism as an attractive conception of the proper relationship between religion and government. For her, secularism is "a metatheoretical position about modes of political justification, rather than a normative, substantive position about the particular ends and values that citizens should pursue" (Laborde 2013, p. 167, emphasis original). "In fact," she continues, "the state should be secular so that citizens do not have to be secular-nonestablishment of religion by the state is what allows the latter [the citizens] freely to exercise the rights associated with freedom of conscience." For example, the French demand that students not exhibit religious symbols by their mode of dress is for Laborde "an illegitimate extension of the demands of secularism from the state to citizens" (see pp. 166-69). Allowing the expression of religious adherence is based on allegiance to the free exercise of religion, not on convictions of the truth of particular religions or of religions in general (p. 181). Liberalism is not itself a religion, as some critics would argue, but instead provides a broad framework within which individual citizens and groups can freely exercise their religious-and nonreligious-beliefs and practices (Laborde 2017, pp. 24-26, 36-40; Laborde 2013, pp. 176-83).

\subsection{Protection for Individual Conscience}

Religion shines in its support for pluralism when it protects the conscientious beliefs and practices of individuals, including those of minority religious groups. And it is the individual who is often overlooked or forgotten in the beliefs and practices of jurisdictional pluralists. To cite just one example of this point (Renkl 2019), in 2019 the archbishop of Indianapolis ordered a Roman Catholic school to fire a teacher in a same-sex marriage. The school had engaged in a long dialogue with the archbishop in defense of the teacher, whose work had been exemplary and whose marriage was protected by the Constitution. The archbishop maintained that it was his duty to oversee "ministerial witnesses" to the faith—teachers-and threatened to strip the school of its Catholic identity if it insisted upon retaining the teacher. This position is supported by the ministerial exception, as teachers are to model religious teaching. But the church hierarchy does not order the firing of teachers who practice birth control or 
who have divorced without seeking a church annulment. It would seem that the church hierarchy picks and chooses which practices are most offensive to it and then penalizes individuals accordingly.

During the same time period, however, when the archbishop of Indianapolis ordered a different Catholic school to dismiss a teacher in a same-sex marriage, the school defied the order, and as a result the archbishop declared that the school could no longer retain its Catholic identity (Taylor 2019). This school is admirable for attending to the dictates of its leaders' own conscientious beliefs even while losing its formal identity. The point here is not that religious schools or places of employment have no right to pressure individuals to conform their conduct to religious teaching. Rather, they should not force individuals to forego "civil enjoyments," or civil rights in Locke's terms, as the price of continued employment. Steven Smith, a jurisdictional pluralist who argues that the area of religion in general should be viewed as an independent jurisdiction, suggests that although the government holds ultimate power, "the law could decide to defer because it respects the church's jurisdiction" (Smith 2016, pp. 20-31; Horwitz and Tebbe 2016, pp. 222-23). The reverse, however, is also true. That is, although the church holds ultimate power over its employees as "ministerial witnesses," it could decide to defer because it respects the individual's conscience. In a liberal democracy, pluralism should extend not only to institutions but also to individuals.

The reporter of the former example recounts an explanation of conscience provided in her religion class when she was in sixth grade in a Catholic school around 1973. In response to a question, the visiting priest said that she must study church teachings, listen to her elders, and pray for discernment. If the result of her scrutiny still conflicted with the church's position, "I was not obliged to follow the church's teaching. In fact, I was obliged to do the opposite: to honor the moral wisdom of my own conscience over the teaching of my church" (Renkl 2019). Historically, the meaning of conscience or of conscientious belief has moved from the idea that persecution for one's beliefs and practices is only truly persecution if these convictions are objectively correct, on the one hand, to the conviction that the persecution of even objectively false beliefs and the resulting practices is persecution, on the other (Murphy 2001, pp. 49, 50, 111, 112, 227-29, 254, 278, 279; Gill 2019, pp. 31-46). The reporter notes that many religious believers today hear little about "the primacy of an informed conscience because many priests take the position that a conscience at odds with the church is by definition insufficiently informed" (Renkl 2019)—a stance not limited of course to the Roman Catholic hierarchy or to the leadership of particular religions.

In the United States, legal religious exemptions frequently protect the religious autonomy of the individual from laws that would force conformity. The most justifiable types protect the individual or groups of individuals, but do not allow the exempted beliefs and practices to be imposed upon those who do not share these convictions. This is why extreme care is needed concerning exemptions for practices that may affect large numbers of people. Issues arise even here, however. Why should beliefs about Sabbath observance, for example, be privileged through exemptions for practices flowing from them, when other types of deeply held beliefs are not? (Gill 2019, pp. 49-56). For some such as Lawrence Sager, "the right to religious autonomy is a deeply flawed idea. Any such right depends on the prior identification of what beliefs and commitments are 'religious' and hence can found a claim to disregard the legal rules that others are obliged to obey" (Sager 2016, pp. 79-85; Gill 2019, pp. 135-42).

Going beyond conventional religious beliefs, however, Supreme Court decisions such as United States v. Seeger (1965) allowed conscientious objections to military service for those whose nontheistic beliefs occupied the same place in their lives that an orthodox theism holds in the lives of conventional objectors. Welsh $v$. United States (1970) allowed exemptions for those whose convictions were religious in a broad moral and ethical sense. Welsh's implication is that to be neutral among religious and secular beliefs, the policy must allow exemptions for all conscientious objections, including those emanating from purely moral, ethical, and philosophical sources (Welsh, 357-358; see, however, Gill 2019, pp. 249-50). This sort of development renders the possibility of exemptions more inclusive, but it also deepens the challenge of determining a stopping point for such claims. I will address the issue of stopping points below. For now, however, I shall highlight two different approaches to 
religious or conscientious objections that contribute to pluralism in a liberal democracy, such as the United States, one concerning exemptions and the other concerning limitations.

\subsection{Exemptions and Their Implications}

The most well-known cases concerning religious exemptions include Sherbert v. Verner (374 U.S. 398 [1963]; see also Hobbie v. Unemployment Appeals Commission 1987). Here the Supreme Court overruled the denial of unemployment compensation to a Seventh-Day Adventist for refusing to work on her sabbath, which was Saturday. By implication this protected all individuals of this religion who are similarly situated. In 1981, however, the Supreme Court in Thomas v. Review Board (1981) ruled that Eddie Thomas could not be denied unemployment compensation by the state of Indiana despite the fact that his refusal to make tank turrets for military tanks was not an objection held by Jehovah's Witnesses in general. Thomas had previously been fabricating sheet steel. A fellow Witness with a more lax interpretation had advised him that making weapons parts was not unacceptable, and the Indiana Supreme Court had found that Thomas's claim was a personal philosophical stance rather than a religious one that would itself still not constitute good cause under Indiana law.

Nevertheless, Chief Justice Warren Burger stated for the court that when Thomas drew a line between making sheet steel and tank turrets, "it is not for us to say that the line he drew was an unreasonable one." The free exercise guarantee is not limited to beliefs on which all members of a religious tradition agree (pp. 715-16). Overall, "Where the state conditions receipt of an important benefit upon conduct proscribed by a religious faith, or where it denies such a benefit because of conduct mandated by religious belief ... a burden upon religion exists. While the compulsion may be indirect, the infringement upon free exercise is nevertheless substantial" (Frazee v. Department of Employment Security 1989, pp. 717-18). This extension of protection beyond members of a recognized religious community parallels that accomplished by Seeger and Welsh for conscientious objectors to military service. It should be noted that this protection is against the application of civil law by the state, not against a religious community's expulsion of members because they dissent from the group's beliefs or practices.

This point bears further development. Before marriage equality, the state's imprimatur on the marriages of only traditional couples was problematic in view of the First Amendment. First, confining civil marriage to opposite-sex couples performed a function akin to a religious establishment ,. It promoted a particular vision of family as the preferred model for all, privileging those who participated in it to the exclusion of those who adhered to a different vision. Although the denial of civil marriage's material benefits was a tangible expression of civic inequality, perhaps more crucial was the symbolic distinction between insiders and outsiders that this exclusion promoted, serving to confirm and entrench the dominant consensus (Gill 2012, pp. 107-44).

Second, the denial of civil marriage to same-sex couples was analogous to a denial of free exercise of religion, if one relies upon an expanded conception of conscientious belief that is individualistic in nature. The historic devaluation of LGBT persons caused them to lose the ability to define their own identities, because their identities were culturally constructed for them by the dominant culture- $a$ form of intolerance that constituted "a violation of the inalienable right to conscience," or "the free exercise of the moral powers of rationality and reasonableness in terms of which persons define personal and ethical meaning in living" (Richards 1999, pp. 18, 70, 74, 90-93, 126-27). Or alternatively, "To be able to search for an understanding of the ultimate meaning of life in one's own way is among the most important aspects of a life that is truly human" (Nussbaum 2000, p. 342; Nussbaum 2008, pp. 19-20, 34-71). The decriminalization of same-sex intimacy satisfied the negative liberty of freedom from interference. In addition, however, a great many people find that marriage enhances their search for personal and ethical meaning. When LGBT individuals were denied the practice of what for many reflected their conscientious beliefs, they were deprived of the ability to make a publicly recognized commitment afforded to traditional couples. Marriage equality instantiated the truth that members of historically 
disadvantaged groups often require a positive right as such to be included in activities or institutions from which they have previously been excluded (Gill 2012, pp. 144-209, especially pp. 186-209).

As we have seen, members of recognized religious traditions are not the only individuals whose free exercise claims deserve consideration. To return to Thomas $v$. Review Board, sole dissenter Justice William Rehnquist argued that the court read the free exercise clause too expansively, thereby violating the establishment clause (Thomas v. Review Board 1981, p. 707, 722, 723). States are not mandated but permitted to grant exemptions for individual benefit from general employment regulations (p. 727). If religion is broadly defined as constituting a conscientious individual search for ultimate meaning in life, however, Thomas cannot be viewed either as favoring one sort of religious belief over another or as favoring religion in its narrower definition over nonreligion. Concerning marriage equality, one can argue that matters of conscience should be reserved for individual determination absent civil injury to others. If same-sex couples want to marry civilly, whether for religious or for moral and ethical reasons that occupy the place of religion in their belief systems, they should be able to do so.

Otherwise, to paraphrase Chief Justice Burger in Thomas, the state conditions the receipt of the important benefits of civil marriage on heterosexual commitments unavailable to same-sex couples, and it denies them these benefits because of the same-sex commitments that do flow from their conscientious convictions. Thomas helps to clarify why individuals who experience same-sex attraction were rightly accorded not only freedom from interference in their intimate relationships, but also positive empowerment to participate civilly in a public institution. Religious communities should not be compelled to solemnize unions that they oppose, whatever type of union is involved. What same-sex couples wanted was the civil solemnization of their unions in the eyes of the state. They sought not necessarily conventional religious legitimacy, but civil legitimacy.

\subsection{Stopping Points}

The possibility of religious or conscientious exemptions promotes pluralism and reinforces the stability of liberal democracy. As mentioned above, however, a troublesome problem with exemptions is identifying stopping points. Sager notes that a functional definition of "religious" commitment "would give anyone with a systematic and deep commitment to any life project, however evil or self-indulgent, a presumptive right to disobey laws that others are required to obey" (Sager 2016, p. 81). If we include broader conscientious commitments that are not specifically religious, the problem deepens. As noted regarding recent Supreme Court decisions, some aspects of pluralism are diminished when religious organizations wield authority over the civil rights of individuals who do not share their beliefs. Religious and conscientious commitments may sometimes be protected, however, not through specific exemptions but through more general policies that are not directed toward religious liberty. Obergefell $v$. Hodges, after all, did not achieve marriage equality by providing conscientious exemptions to existing matrimonial laws to same-sex couples. Rather, it accorded to all individuals the constitutional right to marry the person of their choice.

Partly because the First Amendment's free exercise clause applied only to federal law and partly because of the dominant Protestant social ethos, nineteenth century claims that generally applicable laws burdened religious liberty were rare (Lupu and Tuttle 2014, pp. 180-81). The justifications for protecting religious liberty in early twentieth-century decisions were embedded in the protection of additional rights that were not necessarily religious in nature. Meyer v. Nebraska (1923) upheld the right of a Lutheran school to teach children in German, invalidating a state law prohibiting this practice before eighth grade. Pierce v. Society of Sister (1925) struck down an Oregon law requiring that children attend public schools rather than private ones, religious or otherwise. "These are lynchpins of constitutional law-not as decisions about religious exemptions from otherwise acceptable norms, but rather as decisions about protecting the right of parents to direct their children's education" (Lupu and Tuttle 2014, pp. 183-84). That is, although the protection of religious freedom was not the specific intent, the effects redounded to the benefit of religious practice. Wisconsin v Yoder (1972) granted a religious exemption to the Old Order Amish allowing them to withdraw their children from school 
at age fourteen rather than sixteen based on the burden imposed on religious freedom by Wisconsin law. This decision, however, could instead have been rooted in parents' rights to direct their children's education, as in Meyer and Pierce (Lupu and Tuttle 2014, pp. 192-95).

The Supreme Court has decided several other cases that might appear to be exemptions for religious minorities that in fact protected religious liberty as part of a broad right to expressive liberty, freedom of association, and equality. Cantwell $v$. Connecticut (1940) protected street proselytizing by Jehovah's Witnesses_-and incidentally applied the free exercise clause to the states-but clarified in subsequent cases that this right was not limited to religious persuasion (Lupu and Tuttle 2014, p. 185). In West Virginia Board of Education v. Barnette (1943), the court did not exempt Jehovah's Witness schoolchildren from being forced to salute the American flag while reciting the Pledge of Allegiance. Instead, it simply barred the enforcement of the flag salute, so that "all students have the right to refuse a state-compelled affirmation of political loyalty," whether for religious or other reasons (Lupu and Tuttle 2014, pp. 183-90). Secular and religious claims may have equal moral force under this sort of justification.

Even when the intent is to protect religious freedom, then, the policy doing the work is not always an exemption. When Church of the Lukumi Babalu Aye v. City of Hialeah (1993) struck down the city's ordinance forbidding the ritual killing of animals not primarily for consumption, this was not an exemption for the Afro-Cuban religion of Santeria and its periodic sacrifice of animals that are then cooked and eaten. Rather, it allowed the killing of animals for religious reasons just as it did for secular reasons. The Hialeah City Council had forbidden it here only because of the practice's religious nature, suggesting that it was their Christian moral duty to ban such sacrifices, thereby expressing hostility or animus toward a particular religion. Even Masterpiece Cakeshop v. Colorado Civil Rights Commission (2018) did not grant a religious exemption to Jack Phillips, a Christian baker, for declining to design and bake a cake to celebrate a same-sex wedding. The Supreme Court could have created a broad exemption for those with religious objections to participating in the celebration of same-sex marriages through the provision of refreshments, floral arrangements, or photography. Instead, it was the animus expressed by the Commission toward Phillips's religious beliefs that carried the day. In all of these cases, the protection of religious freedom in ways that expand freedoms in general, as in Barnette's refusal to endorse demonstrations of political loyalty, is preferable to methods that do so by walling off particular groups of believers by giving them exit rights from our common civic project.

\subsection{Exit Rights and Pluralism}

I noted above that the prevailing model governing public funding for religious schools appears to be that when religion partakes of public benefits, it may do so because its mission fulfills a secular purpose or social function that accords with good public policy, in this case enhancing education. This sort of rationale, however, is questionable. More generally, with or without public funding, when policies promote the ability of religious authorities to insulate themselves in ways that impinge upon the civil rights of those who do not share their beliefs, they in effect grant exit rights, in West's terms (West 2016), to these authorities. Such policies allow them to decline to participate in some of our shared social commitments. Exit rights enhance pluralism in allowing dissent from dominant cultural norms. But they detract from the kind of pluralism that enhances individual rights to enter into the practice of these shared social commitments to expressive liberty and equal protection.

The larger point here is that protecting the free exercise of religion is good public policy only insofar as the policy overall is rooted in the liberal democratic values of free and equal citizenship. This is conceptualized differently by different individuals and groups; no set of policies is neutral. My own commitment, however, is to a free and equal citizenship in which the civil rights of individuals are not controlled by those who do not share their beliefs, even if the control is an expansion of religious liberty. Neutrality, then, must be justifiable for nonneutral reasons. It is a "downstream value." That is, neutrality not only requires a context, but it also "assumes that there is some justifiable set of fundamental values, which make no claim to neutrality" (Patten 2014, p. 108). It is these values that 
commit a liberal democracy to neutrality among rival conceptions of the good. "It is because one accepts certain nonneutral values that one thinks that, in some limited domain, the state ought to adopt a stance of neutrality" (Patten pp. 108-11; see Laborde 2017, pp. 147, 148, 202-4). That is, when religious beliefs and practices merit special treatment, it is not specifically because they are religious, but because of the liberal commitment to equal liberty before the law. "Realizing this commitment requires that no citizen can dominate, exclude, or marginalize others' standing or access to the full panoply of liberal rights, even those that claim divine reason as their inspiration" (Hartley and Watson 2018, pp. 118-19). A commitment to pluralism entails good faith efforts to balance freedom of conscience with civil rights when these goals conflict.

\section{Pluralism, Religious Freedom, and LGBT Civil Rights}

One particular area in which current conflicts over the demands of pluralism emerge is in the claims of religious freedom with those of LGBT civil rights. Fear exists on both sides of this divide. The LGBT community fears a resurgence of the pervasive prejudice and discrimination that it has historically encountered and that persists today in many places. The conservative religious community, however, fears coercion that may force individuals and institutions to violate their religious convictions, both now and in the future (Brownstein 2019, pp. 12-15). Those on each side, however, are making "essentially parallel demands on the larger society. Some aspects of human identity are so fundamental that they should be left to each individual, free of all nonessential regulation. Sexual orientation is that fundamental, and for many believers, religious faith is that fundamental" (Laycock 2016, p. 242). To put this differently, "What each side claims as a fundamental human right, the other side sees as a grave evil. One side sees sin; the other sees bigotry" (Laycock 2019, pp. 27, 36; Brownstein 2019). In some contexts, moreover, the desire for power to impose one's viewpoint as the sole locus of morality is in play, as is evident with Christian nationalists. In this section, I address the difficulties of balancing religious freedom and LGBT civil rights in both individual and collective settings.

One type of conscientious objection to providing services for same-sex couples, for example, might build upon health care refusal laws that exempt medical personnel from direct participation in abortions. Although these laws "can facilitate a pluralist regime in which health-care providers and patients with different moral outlooks may coexist," exemptions that do not provide for those with different beliefs "may be understood as part of an effort to build a legal order that would restrict access to abortion services for all" (NeJaime and Siegel 2019, pp. 72-73). NeJaime and Siegel suggest that the same motivations are at work in conflicts over marriage equality. That is, "Religious liberty offers a way to oppose emergent legal orders and newly protected rights," thereby disabling laws concerning which these claimants were the losers in the democratic political process (p. 73). Conscience objections may or may not contribute to pluralist ends. "Religious claimants may speak as a minority and yet assert what have long been the norms of the majority against those whose rights the law has only recently and fragilely come to protect" (NeJaime and Siegel 2019, p. 78; see also 70-71; see also Greenawalt 2019, pp. 108-9). Appropriate accommodations, they suggest, should at least mitigate exemptions' impact upon both the material and dignitary harm of those who do not share the beliefs of objectors, thereby securing the agreement of both those who do and those who do not believe that religious liberty claims are grounded on political aims.

The idea that religious liberty claimants are motivated by political considerations also appears concerning the 2016 report of the United States Commission on Civil Rights, Peaceful Coexistence: Reconciling Nondiscrimination Principles with Civil Liberties. The report recommended only narrow exemptions to civil rights laws lest these exceptions infringe upon civil rights. On its release, Chairman Martin R. Castro stated, “The phrases 'religious liberty' and 'religious freedom' will stand for nothing except hypocrisy so long as they remain code words for discrimination, intolerance, racism, sexism, homophobia, Islamophobia, Christian supremacy or any form of intolerance." He and other commissioners also noted that as with slavery, segregation, and Jim Crow laws, the distortion of 
religion to deny equality to disfavored groups is nothing new (McClain 2019, p. 219; DeGirolami 2019, pp. 271-72).

This sort of hypocrisy, however, cannot be imputed to every religious liberty claimant (Greenawalt 2019, pp. 106-9). In Masterpiece Cakeshop, mentioned above, the Supreme Court ruled that the Colorado Civil Rights Commission had violated the free exercise clause in its deliberations by displaying hostility to religious belief. One commissioner had argued in part that many kinds of discrimination, such as that represented by slavery or the Holocaust, had been historically justified by religious arguments. He stated that "it is one of the most despicable pieces of rhetoric that people can use to-to [sic] use their religion to hurt others" (Masterpiece Cakeshop v. Colorado Civil Rights Commission (2018), slip opinion 13; see pp. 12-13). Justice Anthony Kennedy did not disagree that religious belief has been used to discriminate. He took issue, however, with the description of Phillips's beliefs as despicable and merely rhetorical, and thereby by implication insincere. That is, he implied that we cannot automatically assume that every religious liberty claimant is bigoted or hypocritical. Phillips had declined to design and bake the cake for the gay couple, previously married in Massachusetts, in 2012, when Colorado neither permitted nor recognized same-sex marriages (Wilson 2019, p. 409). We should also recall that in Obergefell v. Hodges (2015), in writing for the court, Kennedy suggested that opposition to marriage equality is based upon "decent and honorable religious or philosophical premises." He continued, however, that when even honorable opposition is enshrined in the law, "the necessary consequence is to put the imprimatur of the State itself on an exclusion that then demeans and stigmatizes those whose own liberty is then denied" (Obergefell, p. 2602). Nevertheless, the point stands in this case, as in the Santeria case mentioned above, that the government should not express animus toward religion and its practice. It should, however, resist religionists' efforts to impose their particular interpretations of morality upon those whose rights are harmed thereby.

Some supporters of exemptions, however, argue that it is proponents of LGBT civil rights laws that qualify for this description. Despite Kennedy's nod toward decent religious convictions, the dissent in Obergefell interpreted the court's ruling as disparaging and disrespecting sincere religious opponents to marriage equality (McClain 2019, pp. 217-21; Perry 2019, pp. 261-66). For Ryan Anderson, a definition of marriage as the conjugal union of a husband and wife and the conviction of some adoption agencies that children deserve both a father and a mother are bases for reasonable disagreement with others, not incentives to discriminate. "Nondiscrimination laws should be a shield to protect, not a sword to demean, stigmatize, and deny liberty" to traditionalist religious believers (Anderson 2019, pp. 366-370). Sexual orientation and gender identify (SOGI) laws, however, on this view are being weaponized against those believers. For many SOGI law supporters, marriage equality in the eyes of the state is not enough; these "relationships must [also] count as marriages in the eyes of their fellow citizens, who must be forced to facilitate such unions" (see also pp. 362, 371-73).

These points are a fair characterization of the views of many religious liberty claimants whose arguments are not grounded in larger political aims. Anderson in particular goes further, however, to distinguish between laws protecting religious liberty and those protecting LGBT civil rights. SOGI nondiscrimination laws coerce people to live in accordance with majority values, whereas religious liberty laws enable all people to live in accordance with their own beliefs and thereby to participate "in the fundamental good of religion, which is itself a constitutive part of the human good." Current SOGI laws, however, "compel people to embrace a new sexual orthodoxy that tears down social barriers to the pursuit of sexual autonomy. But such autonomy is not itself an intrinsic human good or part of the common good," which for him includes traditional marriage and the virtues connected with it (Anderson 2019, pp. 370-73).

I will leave aside discussion of the point that same-sex couples seeking to marry see this goal as traditional couples do, as participation in a human good that is part of the common good. Like religious belief and practice, sexual orientation and intimate life are central constituents of personal identity (Gill 2012). Anderson holds that SOGI laws protect not only LGBT identity but also conduct associated with it; it is the latter that concerns him. Within limits LGBT individuals should be able to 
live out the implications of their identities in the conduct that flows from them, just as within limits religious believers should be able to live out the implications of their own beliefs. Therefore, some attention to possible limits is in order.

\subsection{Businesses, LGBT Rights, and Health Care Refusal Laws}

According to Robin Fretwell Wilson, a good deal of support exists both for protections for religious objectors to marriage equality and for LGBT civil rights. Currently, however, what she terms a purity model is in place throughout most of the United States. As of 2018, twenty-two states, including the District of Columbia, protected people from discrimination in housing, employment, and public accommodations on the basis of sexual orientation and/or gender identity; twenty-nine states offered no state protections in public accommodations. None of these states made fine-grained distinctions, except perhaps Utah's compromise, which is beyond the scope of this project (Adams 2019; Leavitt 2019). Both the faith community and the LGBT community experience this conflict as existential and as a zero-sum game. In almost every state, some people will feel unjustly treated. Wilson recognizes that status and conduct are inseparable: those who refuse to endorse conduct by providing services for same-sex weddings are implicitly condemning status, that of being a gay couple. She therefore suggests that regarding same-sex weddings, we "regulate the business, not individual workers, so that every couple who walks in is served with dignity but no specific individual must perform any given service" (Wilson 2019, pp. 402-412, 419).

Wilson points out that a general rule has never existed that all businesses must serve all comers (Wilson 2019, pp. 413-17). Although the Civil Rights Act of 1964 covers discrimination based upon race, color, religion, or national origin by inns and temporary lodgings, restaurants, service stations, places of entertainment, and establishments that contain these, unlike the Americans with Disabilities Act, it does not include retail and service establishments, social service entities such as adoption agencies, or public gathering places. State laws vary from covering all business establishments of any type as in California, to the specification of particular places similarly to the Civil Rights Act as in Ohio.

For Wilson, businesses should be regulated under law even regarding "religiously infused services" (p. 412), but individuals, even business owners, should not. Regarding services such as refreshments, flowers, and photography for weddings, a business owner could hire a new, willing employee if the current staff has religious objections, or the owner could undertake contractual arrangements to partner or subcontract as needed with similar businesses where the employees do not entertain such objections. Failing these arrangements, business owners themselves would be required personally to provide the requested services despite religious objections. Either way, "the business remains on the hook contractually for the service, is liable for breach, and must ensure performance-just as businesses do when acting through employees." People should not be rejected by businesses open to all, but individuals of faith should be able to operate businesses without violating their religious commitments. "Bakeries cannot be choosers. But individual business owners should be allowed to decide how the cake is baked" (see pp. 417-20).

This suggested compromise promotes both pluralism and the stability of liberal democracy by honoring the identities and commitments of both the faith community and the LGBT community. It protects the conscientious beliefs and practices of individuals in each of these groups. It will mollify neither those who think that any cooperation with LGBT couples amounts to complicity in sin, nor those who hold that religious objections are pretextual screens to enable anti-LGBT discrimination. It does, however, avoid the harm to some religious business owners of having to decide, for example, not to service weddings of any kind. It also avoids the dignitary harm to LGBT individuals of suggested signage on storefronts or messages on websites that same-sex weddings are not serviced by those businesses, although the resulting stigma to businesses some think would practically end discrimination (Laycock 2008, p. 200; Koppelman 2015, p. 620).

Wilson's distinction between institutions and individuals is serviceable in venues other than bakeries, catering establishments, florist shops, and photography studios. In 1973, Congress passed 
the Church Amendment, stipulating that an entity's receipt of federal funds did not authorize any public authority, including a court, to require either that an individual be involved in any sterilization or abortion procedure contrary to that individual's religious or moral convictions, or to require that the recipient entity allow any sterilization or abortion procedure contrary to what is allowed to that entity on the basis of religious or moral convictions. Webster v. Reproductive Health Services (1989) later made clear that public employees and public hospitals, as well as private and religiously associated hospitals, were protected from this participation. In 1996, the Danforth Amendment prohibited any level of government from discriminating against entities that eschewed abortion training, abortions, or referrals for training or abortions, also protecting doctors, medical students, and health training programs. Refusals could be for any reason, not simply for religious or ethical ones. Finally, the Weldon Amendment in 2004 reinforced these protections by withholding certain federal appropriations from any level of government that might discriminate against health care entities that did not provide, pay for, or refer for abortions, although the provision of abortions in cases of rape, incest, or threats to life did not risk the loss of federal funds (Wilson 2008, pp. 81-86).

These accommodations are correct where they protect individual medical providers from involvement in sterilizations and abortions, although they should be required to assist in medical emergencies and possibly in other situations where no one else is available, just as business providers of services for same-sex marriages should be required to serve clients in the failure of possible seamless alternative arrangements described above. Moreover, in both the health care and the marriage contexts, accommodations should be limited to those directly involved in the provision of services. The nurse providing instruments to a doctor in an abortion is directly involved; the individual registering a hospital patient is not (Greenawalt 2019, pp. 104-9). The baker, caterer, florist, or photographer sought for a same-sex wedding is directly involved (Laycock 2019, p. 29); the individual answering the phone at a business that supports marriage equality is not. The conscientious concerns of individuals should be paramount as long as their protection does not cause harm to the safety of those who need reproductive health services or the civil rights of those who desire services in connection with same-sex weddings. Pluralism demands no less. The issue of accommodations becomes more troublesome, however, regarding institutions and even their employees where policies affect many individuals who do not share the beliefs of those in authority.

\subsection{Marriage Licenses and Pharmacies}

Despite the fact that in the United States clergy who preside at marriages are agents of the state, it is highly unlikely that they will ever be forced to celebrate same-sex marriages (Eskridge 2019; Wilson 2008, pp. 86-90). Although the context might be different if no institution of civil marriage existed through which same-sex couples could access both the material and the social benefits of marriage and if no religion would celebrate same-sex marriages, religious communities are entitled internally to live by their own beliefs. Pluralism should reign.

Civil marriage, however, falls under a different rubric when county clerks or judges feel conscience-bound to deny marriage licenses to same-sex couples. They are employed by the state and perform a public function. If an objector is the only appropriate official available in a small county office, "the denial is tantamount to a denial of access to marriage" (Wilson 2008, pp. 97-100)—at least in that venue. The well-known case of Kim Davis, county clerk of Rowan County, Kentucky, who spent some time in jail for civil contempt after refusing to sign marriage licenses for same-sex couples, is relevant here. The Kentucky legislature eventually created a uniform marriage license form that does not bear the names of county clerks, solving the problem of conscience-based individual objections. Alternatively, although country clerks like Davis may hold deep religious beliefs, they do not as individuals constitute the office. If one or another county clerk can seamlessly and invisibly process all comers by issuing licenses as well as by presiding at marriages when necessary, the state office as a public entity cannot be viewed as aligning itself with religion. If public offices can use informal arrangements to staff around objectors so that a willing official is always available and all couples can experience a seamless transaction, that solution 
may work (Tebbe 2017, pp. 164-81; Greenawalt 2019, p. 109). One does wonder, however, whether accommodations would be available to county clerks or their deputies who hold religious objections to remarriages or to interfaith unions (Gill 2019, pp. 177-79).

Similar issues arise in private businesses with pharmacists who object to dispensing emergency contraception if they believe it may function as an abortifacient, with the added urgency that here, timing is essential for the patient. Especially in rural areas or at odd times of day, only one pharmacist at one pharmacy may be available. Moreover, contraceptives are often prescribed for reasons other than birth control. Some women have health reasons for not becoming pregnant. What if a pharmacist has conscientious objections to selective serotonin reuptake inhibitors such as Prozac for attention deficit hyperactivity disorder because she conscientiously believes that too many children are mistakenly medicated or overmedicated for this condition? For these reasons, in the absence of the possibility of a seamless handoff, pharmacists should be required to dispense all medications in line with valid prescriptions. Although the burden on conscientious beliefs may be grave to the provider, it is graver for some individuals to be impeded from living their own lives as they see fit because of the objections of others who are not directly affected by their actions (Gill 2019, pp. 179-80; Stewart 2019, pp. 240-41).

An emphasis upon the existence of alternatives has been a drumbeat throughout this article. Accommodations that ensure that those seeking social services or any of the other contingencies above while also protecting the consciences of those providing them contribute to pluralism. The Boy Scouts' former exclusion of LGBT participants, mentioned above, was acceptable because other organizations existed or could be created without that exclusivity. If a critical mass of social service organizations or commercial establishments, however, did share parallel criteria of exclusivity, as in the regime of Jim Crow in the South, accommodations and exemptions would counteract pluralism rather than foster it. We might be forced to admit that we no longer possess the context of choice or the forum that should characterize a liberal political culture or of liberal democracy (Gill 2019, pp. 105-15).

\subsection{Religious Freedom and Institutions}

Achieving a balance between religious freedom and civil rights is trickier regarding institutions than it is with individuals. The commitments of institutions, employees, and clients are all at stake. The health care venue again provides examples, but instead of providing for the conscientious beliefs of individuals, in these cases exemptions can infringe upon patients in settings where they have few alternatives. In recent years, a number of secular hospitals have merged with Roman Catholic medical institutions. This means that Catholic doctrine regarding reproductive health care has been extended to hospitals that formerly provided contraceptives, sterilizations, abortions, and varied infertility services but can no longer do so (Sepper 2016, pp. 312-18; Wilson 2016, pp. 274-79). Many Catholics as well as others disagree with the official position of the Roman Catholic Church. But alternative hospitals for patients desiring these services may not exist in the area. Furthermore, the increase in health maintenance and preferred provider organizations means that individuals are often limited at the outset by their employers' health benefit plans. Religious nonprofits can and do receive public funding (Bowen v. Kendrick, 487 U.S. 589 [1988]), and hospitals are separately incorporated from churches, synagogues, temples, or mosques-which at least in theory should mean that they must follow generally applicable laws. Those in a secular hospital who oppose certain health care options need only decline objectionable services; those who desire unavailable services in a faith-based setting are stuck.

This scenario is not hypothetical. In 2009, an Illinois woman on her doctor's advice sought to end her pregnancy after her water broke at twenty weeks, as the fetus had exhibited severe anomalies and an infection risk existed. Her supposedly secular hospital denied her request for nearly two months, however, until she hemorrhaged, brought in items she had soaked through, and the hospital personnel actually estimated the amount of blood she had lost. Unknown to the patient, the hospital had merged in 1994 with a Catholic hospital in Iowa and was a "zombie religious hospital" — a secular hospital operating under Catholic religious restrictions, which dictated that it "must consider only grave and 
imminent threat to maternal health" (Russell-Kraft 2016, pp. 12-13; Stewart 2019, pp. 235-44; Gill 2019, pp. 84-85). Stewart herself experienced a miscarriage when pregnant with her second child. After bleeding heavily at home in New York City, she was taken by ambulance to the nearest hospital, which happened to be a Catholic facility. Her blood pressure was low and she was in and out of consciousness. Hospital attendants periodically changed her bloody sheets, but did nothing else. When she pointed out to a passing emergency room doctor that she was bleeding out and asked for an examination, the doctor "balled up her fists, scrunched her face, and walked away." After going into shock, Stewart finally received the dilation and curettage that she had needed from the outset. "I later learned that I lost nearly 40 percent of my blood. Only then did the hospital provide me with the abortion that saved my life" (Stewart 2019, pp. 246-47).

Religion contributes to pluralism when it is employed to protect the conscientious beliefs of individuals. It detracts from pluralism when it deprives people of or endangers them in their civil enjoyments, in Locke's terms, on the basis of the religious beliefs of others. This conflict appears currently in the intersection of religious belief in the health care setting with LGBT civil rights. In 2019, the Trump administration's Department of Health and Human Services (HHS) issued a "Denial of Care" rule allowing almost any health care worker-doctors, nurses, paramedics, orderlies, and receptionists - to withhold care from patients on the basis of religious or moral beliefs. The rule was silent regarding contingencies in which no one without objections might be available to treat the patient. In response, health providers cited numerous examples over the years of LGBT individuals being belittled or turned away in health care settings, including a gay man with a possible heart attack being derided by a paramedic, who refused to transport the patient to the hospital (Hayes 2019, p. 10). Noncompliance risks the loss of federal funding.

In 2020, HHS finalized the rule withdrawing protection from transgender patients against discrimination by doctors, hospitals, and health insurance companies. Although the Obama administration had interpreted sex discrimination to include gender identity, the Trump administration disagreed, maintaining that health providers and insurers could still create their own policies in this area rather than be forced to submit to the interpretations of federal bureaucrats (Sanger-Katz and Weiland 2020). Some might suggest that "local option" policymaking contributes to pluralism. When patients must depend for proper care upon whom they encounter where in the medical system, however, this sort of pluralism is unworthy of a liberal democracy.

In other areas also in 2020, the Trump administration took actions that harm LGBT individuals. It did so not by presenting explanations as to why these moves constitute good public policy, but rather to appeal to conservative Christians. The Department of Education rescinded rules from the Obama administration allowing transgender students to use bathrooms or to participate in sports corresponding to their gender identities. The Justice Department initiated a rollback of protections for transgender individuals in federal prisons. The Office of Personnel Management suspended protections for transgender employees of federal contractors. Finally, the Department of Housing and Urban Development (HUD) issued a rule that would allow single-sex homeless shelters to exclude transgender individuals from facilities that correspond to their gender identities. HUD Secretary Ben Carson has expressed concern about "big hairy men" in women's shelters because they say they are women. LGBT rights groups, however, contend that the detailed screening methods for identifying transgender individuals will allow the exclusion of cisgender women, who, for example, may have unusual amounts of body and facial hair (Cameron 2020). Although the case's long-term impacts are unclear, all of this is despite the Supreme Court's decision in Bostock v. Clayton County (2020), ruling that discrimination on the basis of sex includes sexual orientation and gender identity. That is, if individuals suffer discrimination because of their sexual orientation or gender identity, they have been discriminated against on the basis of sex. Conservative Christians emphasize the necessity of defending traditional Christian beliefs and religious practices, but they are often speaking for a minority of Christians while also imposing their policies on both Christians and non-Christians who do not share them. 


\subsection{Religious Discrimination, Employment, and Adoptions}

Despite recent judicial decisions concerning the uniqueness of the ministerial exception, religious organizations can hire and fire their employees based on their religious faith even if they are janitors (Corporation of the Presiding Bishop of Jesus Christ of Latter-day Saints v. Amos 1987). A review of the 1972 amendments to Title VII of the 1964 Civil Rights Act demonstrates, however, that religious organizations are not necessarily authorized to discriminate concerning religion in government-funded employment. Moreover, when public funds are at issue, Amos itself permitted but did not require the government to allow religious organizations to discriminate in employment based on religion (Rogers 2005, pp. 108-13). This point is particularly relevant to the faith-based initiative, discussed above, as public funds were designated only for nonreligious activities even when these were administered by religious organizations and houses of worship. When "people are disqualified from holding government-funded jobs because they aren't the 'right' religion, the government plays a key role in making religion relevant to citizens' standing in the political community, which is inconsistent with constitutional and policy values" (p. 117).

Prior to the Trump administration, religious organizations that accepted government contracts prohibiting discrimination based on sexual orientation or gender identity were not automatically exempt from these rules, just as they had to follow rules against discrimination on the basis of race, sex, or national origin. In 2019, however, Trump's Department of Labor (DOL) proposed a rule allowing a religious exemption for both government contractors and closely held businesses "so long as they could point to a religious purpose that is a public part of their mission and demonstrate that they exercise their religion in order to further that purpose." This exemption, for example, could cover religious conduct codes such as those prohibiting sex outside heterosexual marriage, or perhaps turning away job applicants because of religious objections to their marriage - which will be more likely to focus upon same-sex marriages than upon interracial or interfaith marriages. "According to the DOL, the rule is to be construed in favor of the broadest possible protection for religious interests" (Rogers 2019, pp. 113-18). This broadest possible protection, however, seems perilously close to elevating religious freedom above all other rights, some of the difficulties with which were discussed above.

Although they are generally regulated by the states, not the federal government, the practices of adoption agencies have become a focus of controversy. In most states they must be licensed. In essence these agencies are licensed or deputized by the government to supply services that otherwise the government itself would have to provide, at least under modern expectations. License requirements may allow states to prohibit discrimination against same-sex couples, but some states have passed exemptions permitting religious adoption agencies to reject same-sex couples wanting to adopt-but only if they do not receive public funding (Tebbe 2017, pp. 124-26). Because Catholic Charities does receive public funds, in 2006 Catholic Charities of Boston terminated child placement altogether rather than place children with same-sex couples. Catholic Charities of Illinois, however, terminated its relationship with the Catholic Church in 2011 in order to continue child placement on a nondiscriminatory basis. Religious adoption agencies have not been permitted to exclude other couples-remarried or interfaith, for instance-on theologically based grounds. Why should they be able to exclude same-sex couples, one might ask, even if they do not receive public funds? (Tebbe, pp. 136-37; see Ball 2017, pp. 225-26; Warbelow 2019, p. 438).

In 2019, the Trump administration's HHS proposed a rule applicable to all HHS programs, allowing publicly funded adoption and foster care agencies to refuse to work with families failing to meet strict religious tests that mainly affect religious minorities and LGBT people (Boston 2019). Previously in 2019, the administration had granted a waiver from an Obama administration rule that federally funded adoption agencies must accept all families to South Carolina's Miracle Hill Ministries, a large foster-family provider. Miracle Hill families must "sign a doctrinal statement affirming that marriage is between a man and a woman, and refuting the existence of transgender people altogether." LGBT children may be fostered by families who deny their identities, or may languish in institutional care without a family. The new rule renders the waiver a national policy (Boylan 2019). One aspiring foster mother, Aimee Maddonna, was rejected because she is of the "wrong" religion-Catholic—and 
the agency told her that it only works with evangelical Christians. This case is now in litigation against both the state and federal governments (Aimee Madonna v. U.S. Department of Health and Human Services 2020; Boston 2020). A lesbian couple is also suing state and federal officials, "arguing that allowing Miracle Hill to receive taxpayer money while it screens applications on religious criteria violates the U.S. Constitution" (Church and State 2020).

Meanwhile, the Supreme Court in 2020 accepted a case that will decide whether Philadelphia may exclude a Catholic Social Services foster care agency from the city's foster care system because it will not work with same-sex couples (Fulton v. City of Philadelphia 2020). The agency maintains that its policies accord with its rights to religious freedom and free speech, relying on arguments that it was subject to religious hostility similar to that at issue in Masterpiece Cakeshop. An ACLU lawyer argues, however, that if foster care agencies are allowed to reject otherwise-qualified families for religious reasons unrelated to their ability to care for children, thousands of children may fail to receive proper care (Liptak 2020).

These types of controversies differ in many ways from some of the issues discussed above. Although adoption and foster care agencies are often religiously affiliated, they are performing a public function or service that the government itself would otherwise have to provide. There is no possibility of seamless transactions as with businesses providing services connected with same-sex weddings, as clients who are turned away must approach a different adoption agency themselves. There is also no possibility of seamless transactions as in county clerks' offices, where requests for marriage licenses may be shifted to another agency employee, as presumably employees who work there agree with the agency's philosophy. At least where public funds are involved, these agencies should serve all clients who are qualified to care for children on the basis of professional standards. Confusing the issue in these sorts of areas, I believe, is confusion over the meaning of religious belief when exemptions are sought.

The narrowest type of exemption for religious institutions concerning religious belief refers to the ability to hire or retain employees on the basis of religious faith, meaning those of the same religion as that grounding the institution. If an institution insists that its clients must also subscribe to its religious faith, this broadens the exemption considerably. Beyond this, an institution may insist that its clients share the same interpretation of its faith that it holds itself. Aimee Maddonna was found wanting not because she is not Christian, but because she is a Catholic rather than an evangelical Christian. Concerning the rejection of LGBT clients, the same difficulty presents itself. A great many Christians believe that LGBT individuals are or can be excellent parents. Christians who reject this belief, therefore, are subscribing to a particular interpretation of Christianity not shared by all Christians or by all with religious beliefs of other kinds. An agency with strict religious tests can only serve a small range of potential clients. Even if a great many agencies exist, if each potentially has narrow criteria for those with whom it will work, the situation becomes untenable. In theory, pluralism exists as a range of options among which potential clients may choose. But if each is exclusive, even if exclusive in different ways, potential clients could face undue burdens as they comb through the ostensible choices to find agencies that match their identities. Faith-based agencies that exclude should not be receiving public funding, whether the exclusivity is based upon religion, race, national origin, sexual orientation, or gender identity.

\subsection{Race Versus Sexual Orientation and Gender Identity}

Many traditional religious believers reject the idea of racial discrimination hypothetically grounded on religious belief but simultaneously justify a degree of discrimination toward LGBT individuals. Clear religious teachings against same-sex intimacy exist, they suggest, that do not have parallels in teachings supporting subordination on the basis of race (Laycock 2016, pp. 252-53). Others debate the extent to which these types of discrimination have different rationales (Smith 2019, pp. 239-42; Melling 2019, pp. 252-54; Warbelow 2019, pp. 424, 425, 428). Still others, however, point to white Americans, with or without slaves, who believed that biblical references to slavery meant that it was 
divinely sanctioned (Griffith 2017, pp. 85-87) and that post-emancipation segregation was justified (Babst and Compton 2016, p. 101; Jones 2020). If racists and segregationists had received religious exemptions from civil rights laws, these regulations would have been toothless in many instances (Koppelman 2015, pp. 642,653). More generally, if the courts were to exempt dissenters, religious or not, from the application of antidiscrimination laws because of their "disparate impact" on those who wish to discriminate, "it would bring the application of antidiscrimination law, as we know it, to a grinding halt" (Ball 2017, pp. 218-21).

It seems clear that both white supremacy, preserved in part through antimiscegenation laws, and heterosexism, or the privileging of straight over LGBT people, have been ways of life supported by complex systems of belief. Where Loving $v$. Virginia (1967) in part overturned the preservation of white supremacy by legitimizing interracial marriage, Obergefell $v$. Hodges in part overturned a caste system that has privileged heterosexuality over nonheterosexuality. Each hierarchy targets one group of people as inferior to another (Gill 2012, pp. 18-25, 60-65). Regardless of the degree to which each has been rooted in religious principles, both have been destructive. A society should not pull its punches in aiding one group because its members may not have suffered as much or as long as the members of a different group. A more recent variation on this theme suggests, as we have seen, that while reasonable disagreement exists as to the legitimacy of same-sex marriage, outdated expressions of white supremacy are by implication insincere (Laycock 2008, pp. 195, 196; Wilson 2008, p. 101; Ball 2017, pp. 271-73). Recent violence against Jews and African-Americans, however, has revealed good-faith beliefs by Christians and white supremacists that are obviously sincere. Defenses of racial and of heterosexual superiority still parallel each other more than we might like to think.

Finally, some who seek or who have exemptions from honoring LGBT civil rights may accuse LGBT equality advocates of holding a double standard. As described above, some tend to distinguish between the status of being LGBT, on the one hand, and the conduct of those who, for example, want to celebrate marriages. The status is fine; the conduct is not. But penalizing conduct in effect penalizes status as well: only same-sex couples celebrate same-sex marriages. Religious traditionalists may argue similarly against LGBT equality advocates. These advocates imply that they do not object to religious convictions against marriage equality, or transgender identity-the status-but only to discrimination against these individuals' desired actions - the conduct. But only religious convictions give rise to conscientious refusals, for example, to treat transgender individuals in a medical setting. Therefore, penalizing this conduct also penalizes status, or the beliefs that give rise to these refusals.

This analogy is correct in theory. But in a liberal society and state, it is not religious believers who should create the scope of their own jurisdictions, or the limits of their own areas of competence (Laborde 2017, pp. 161-71). Plenty of room for argument exists as to where this line should be drawn, and I have attempted to draw some lines here. Without an entity with jurisdictional sovereignty, antidiscrimination laws would hold no authority, whether the discrimination they were to counteract involved, race, sex, sexual orientation and gender identity, or even religion itself. No dispensation is neutral. Although religious convictions should be heeded, they should not be accorded preeminence.

\section{Conclusions}

This article may seem unduly critical of religion's influence on pluralism, or at least upon an interpretation of pluralism that emphasizes individual conscience over that of religious organizations and institutions. Nevertheless, as put by Robert Jones, a general condemnation of religion "fails to account for the positive, even noble acts of humanity that are inspired by religious commitment and devotion." Although a detailed balancing of good versus evil inspired by religion is impossible, "it is at least clear that many of our nation's achievements and critical moments in our history such as the civil rights movement may have been stillborn without their religious DNA" (Jones 2016, pp. 223-27).

This article began with Rosenblum's description of the religious values promoted by moral integralists - to promote the public good - and by civic integralists - to reinforce democratic values by promoting greater pluralism. The civil rights movement enshrined both of these values. Not incidentally, 
moreover, it sought the freedom of individuals from oppressive cultural forces. In this sense, it was countercultural, as religion often is, within the context of its time. But the quality of "counterculturalness," so to speak, is not always positive. White Christians in the South, for example, were countercultural in their long resistance to civil rights (Jones 2016, pp. 219-21). Christian nationalists today see themselves as countercultural in their desire to reclaim what they view as the only legitimate identity of the American nation. A countercultural orientation, therefore, does not always promote pluralism or promote the stability of liberal democracy. Christian nationalists, as mentioned above, are correct to assert that no public policy is neutral. Religion makes its greatest contributions to pluralism, however, when allied with movements to enhance individual rights, including but definitely not limited to the free exercise of religion.

Funding: This research received no external funding.

Conflicts of Interest: The author declares no conflict of interest.

\section{References}

\section{Archival Sources}

Aimee Maddonna v. U.S. Department of Health and Human Services. 2020. 6-19-cv-3551-TMC.

Bostock v. Clayton County. 2020. 590 U.S.

Bowen v. Kendrick. 1988. 487 U.S. 589.

Boy Scouts of America v. Dale. 2000. 530 U.S. 640.

Burwell v. Hobby Lobby Stores. 2014. 134 S. Ct. 2751.

Cantwell v. Connecticut. 1940. 310 U.S. 296.

Church of the Lukumi Babalu Aye v. City of Hialeah. 1993. 508 U.S. 520.

Corporation of the Presiding Bishop of the Church of Jesus Christ of Latter-Day Saints v. Amos. 1987. 483 U.S. 327.

Employment Division v. Smith. 1990. 494 U.S. 872.

Espinoza v. Montana Department of Revenue. 2020. No. 18-1195.

Frazee v. Department of Employment Security. 1989. 489 U.S. 829.

Fulton v. City of Philadelphia. 2020. No. 19-123.

Good News Club v. Milford Central School. 2001. 533 U.S. 98.

Hobbie v. Unemployment Appeals Commission. 1987. 480 U.S. 136.

Hosanna-Tabor Evangelical Lutheran Church and School v. EEOC. 2012. 132 S. Ct. 694.

Little Sisters of the Poor v. Pennsylvania. 2020. No. 19-431.

Loving v. Virginia. 1967. 388 U.S. 1.

Masterpiece Cakeshop v. Colorado Civil Rights Commission. 2018. 594 U.S.

Meyer v. Nebraska. 1923. 262 U.S. 390.

Obergefell v. Hodges. 2015. 135 S. Ct. 2584.

Our Lady of Guadalupe v. Morrissey-Berru. 2020. No. 19-267.

Pierce v. Society of Sisters. 1925. 268 U.S. 510.

Reynolds v. United States. 1879. 98 U.S. 145.

Rust v. Sullivan. 1991. 500 U.S. 173.

Sherbert v. Verner. 1963. 374 U.S. 398.

Thomas v. Review Board. 1981. 450 U.S. 707.

Trinity Lutheran Church v. Comer. 2017. 127 S. Ct. 2012.

Trump v. Pennsylvania. 2020. No. 19-454.

United States v. Seeger. 1965. 518 U.S. 515.

Webster v. Reproductive Health Services. 1989. 492 U.S. 490.

Welsh v. United States. 1970. 398 U.S. 333.

West Virginia Board of Education v. Barnette. 1943. 319 U.S. 624.

Widmar v. Vincent. 1981. 454 U.S. 263.

Wisconsin v. Yoder. 1972. 406 U.S. 205. 
Zelman v. Simmons-Harris. 2002. 530 U.S. 639.

\section{Published Sources}

Adams, Senator J. Stuart. 2019. Cultivating Common Ground: Lessons from Utah for Living with Our Differences. In Religious Freedom, LGBT Rights, and the Prospects for Common Ground. Edited by William N. Eskridge Jr. and Robin Fretwell Wilson. Cambridge: Cambridge University Press, pp. 441-59.

Anderson, Ryan T. 2019. Challenges to True Fairness for All: How SOGI Laws Are Unlike Civil Liberties and Other Nondiscrimination Laws and How to Craft Better Policy and Get Nondiscrimination Laws Right. In Religious Freedom, LGBT Rights, and the Prospects for Common Ground. Edited by William N. Eskridge Jr. and Robin Fretwell Wilson. Cambridge: Cambridge University Press, pp. 361-77.

Babst, Gordon A. 2002. Liberal Constitutionalism, Marriage, and Sexual Orientation: A Contemporary Case for Dis-Establishment. New York: Peter Lang.

Babst, Gordon A., and John W. Compton. 2016. Equal Citizenship and Religious Liberty: An Irresolvable Tension? In Citizenship and Immigration-Borders, Migration and Membership in a Global Age. Edited by Ann E. Cudd and Win-chiat Lee. Cham: Springer, pp. 91-104.

Ball, Carlos. 2017. The First Amendment and LGBT Equality: A Contentious History. Cambridge: Harvard University Press. Belluck, Pam. 2019. Planned Parenthood Opts Out Over Trump Rule. New York Times, August 20, A1, A14.

Benner, Katie. 2020. Religious Freedom Training by Justice Dept. Raises Red Flag for Lawyers. New York Times, March 14, A17.

Berg, Thomas C. 2019. Freedom to Serve: Religious Organizational Freedom, LGBT Rights, and the Common Good. In Religious Freedom, LGBT Rights, and the Prospects for Common Ground. Edited by William N. Eskridge Jr. and Robin Fretwell Wilson. Cambridge: Cambridge University Press, pp. 307-25.

Boston, Rob. 2019. Driving Discrimination. Church \& State 72: 6.

Boston, Rob. 2020. Federal Court Allows S.C. Mother's Lawsuit to Proceed against Government-Sponsored Religious Discrimination in Foster Care. Washington, DC: Press Release, Americans United for Separation of Church and State.

Boylan, Jennifer Finney. 2019. Trump's Latest Victims. New York Times, August 8, A23.

Brady, Kathleen A. 2004. Religious Organizations and Free Exercise: The Surprising Lessons of Smith. Brigham Young University Law Review 5: 1633-714.

Brownstein, Alan. 2019. Choosing among Non-negotiated Surrender, Negotiated Protection of Liberty and Equality, or Learning and Earning Empathy. In Religious Freedom, LGBT Rights, and the Prospects for Common Ground. Edited by William N. Eskridge Jr. and Robin Fretwell Wilson. Cambridge: Cambridge University Press, pp. 11-23.

Cameron, Chris. 2020. Trump Advances Limits for Transgender Rights. New York Times, July 25, A16.

Church and State. 2020. Lesbian Couple in S.C. Wins Right to Challenge Discrimination in Foster Care. Church $\mathcal{E}$ State 73: 21.

Cole, David. 2001. Faith Succeeds Where Prison Fails. New York Times, January 31, A25.

DeGirolami, Marc O. 2019. On the Uses of Anti-Christian Identity Politics. In Religious Freedom, LGBT Rights, and the Prospects for Common Ground. Edited by William N. Eskridge Jr. and Robin Fretwell Wilson. Cambridge: Cambridge University Press, pp. 267-78.

Eskridge, William N., Jr. 2019. Marriage Equality, Traditionalist Churches, and Tax Exemptions. In Religious Freedom, LGBT Rights, and the Prospects for Common Ground. Edited by William N. Eskridge Jr. and Robin Fretwell Wilson. Cambridge: Cambridge University Press, pp. 281-94.

Formicola, Jo Renee. 2003. The Good in the Faith-Based Initiative. In Faith-Based Initiatives and the Bush Administration: The Good, the Bad, and the Ugly. Edited by Jo Renee Formicola, Mary C. Segers and Paul Weber. Lanham: Rowman \& Littlefield, pp. 25-61.

Galston, William A. 1991. Liberal Purposes: Goods, Virtues, and Diversity in the Liberal State. New York: Cambridge University Press.

Gill, Emily R. 2001. Becoming Free: Autonomy and Diversity in the Liberal Polity. Lawrence: University Press of Kansas.

Gill, Emily R. 2012. An Argument for Same-Sex Marriage: Religious Freedom, Sexual Freedom, and Public Expressions of Civic Equality. Washington, DC: Georgetown University Press.

Gill, Emily R. 2019. Free Exercise of Religion in the Liberal Polity: Conflicting Interpretations. Cham: Palgrave Macmillan. 
Green, Erica. 2018. DeVos Pushes Federal Aid for Religious Universities. New York Times, May 10, A16.

Greenawalt, Kent. 2019. Mutual Tolerance and Sensible Exemptions. In Religious Freedom, LGBT Rights, and the Prospects for Common Ground. Edited by William N. Eskridge Jr. and Robin Fretwell Wilson. Cambridge: Cambridge University Press, pp. 102-10.

Griffith, R. Marie. 2017. Moral Combat: How Sex Divided American Christians and Fractured American Politics. New York: Basic Books.

Hartley, Christie, and Lori Watson. 2018. Political Liberalism and Religious Exemptions. In Religious Exemptions. Edited by Kevin Vallier and Michael Weber. New York: Oxford University Press, pp. 97-129.

Hayes, Liz. 2019. Will You Be Denied Medical Assistance Because of Someone Else's Religion? Church E State 72: 9-11. Hayes, Liz. 2020. Reckless Rules. Church E State 73: 14-15.

Helfand, Michael A. 2019. Implied-Consent Religious Institutionalism: Applications and Limits. In Religious Freedom, LGBT Rights, and the Prospects for Common Ground. Edited by William N. Eskridge Jr. and Robin Fretwell Wilson. Cambridge: Cambridge University Press, pp. 134-49.

Hill, B. Jessie. 2019. God and Man and Religious Exemptions in the Modern University. In Religious Freedom, LGBT Rights, and the Prospects for Common Ground. Edited by William N. Eskridge Jr. and Robin Fretwell Wilson. Cambridge: Cambridge University Press, pp. 344-57.

Hollinger, Dennis. 2019. Religious Freedom, Civil Rights, and Sexuality: A Christian Ethics Perspective. In Religious Freedom, LGBT Rights, and the Prospects for Common Ground. Edited by William N. Eskridge Jr. and Robin Fretwell Wilson. Cambridge: Cambridge University Press, pp. 56-66.

Hollman, Holly. 2019. Why Money Matters: LGBT Rights and Religious Freedom. In Religious Freedom, LGBT Rights, and the Prospects for Common Ground. Edited by William N. Eskridge Jr. and Robin Fretwell Wilson. Cambridge: Cambridge University Press, pp. 294-306.

Hoogstra, Shirley V., Shapri D. LoMaglio, and Brad Crofford. 2019. Educational Institutions in the Age of Same-Sex Marriage. In Religious Freedom, LGBT Rights, and the Prospects for Common Ground. Edited by William N. Eskridge Jr. and Robin Fretwell Wilson. Cambridge: Cambridge University Press, pp. 329-43.

Horwitz, Paul, and Nelson Tebbe. 2016. Religious Institutionalism-Why Now? In The Rise of Corporate Religious Liberty. Edited by Micah Schwartzman, Chad Flanders and Zoë Robinson. New York: Oxford University Press, pp. 207-26.

James, Scott. 2019. Religion's Pension Crisis: A 1974 Federal Law May Hurt Pensioners around the Country. New York Times, September 12, F7.

Jones, Robert P. 2016. The End of White Christian America. New York: Simon \& Schuster.

Jones, Robert P. 2020. White Too Long: The Legacy of White Supremacy in American Christianity. New York: Simon \& Schuster.

Koppelman, Andrew. 2013. Defending American Religious Neutrality. Cambridge: Harvard University Press.

Koppelman, Andrew. 2015. Gay Rights, Religious Accommodations, and the Purpose of an Antidiscrimination Law. Southern California Law Review 88: 619-59.

Laborde, Cécile. 2013. Justificatory Secularism. In Religion in a Liberal State. Edited by Gavin D'Costa, Malcolm Evans, Tariq Madood and Julian Rivers. New York: Cambridge University Press, pp. 164-86.

Laborde, Cécile. 2017. Liberalism's Religion. Cambridge: Harvard University Press.

Laycock, Douglas. 2008. Afterward. In Same-Sex Marriage and Religious Liberty: Emerging Conflicts. Edited by Douglas Laycock, Anthony R. Picarello Jr. and Robin Fretwell Wilson. Lanham: Becket Fund for Religious Liberty and Rowman \& Littlefield, pp. 189-207.

Laycock, Douglas. 2016. The Campaign against Religious Liberty. In The Rise of Corporate Religious Liberty. Edited by Micah Schwartzman, Chad Flanders and Zoë Robinson. New York: Oxford University Press, pp. 231-55.

Laycock, Douglas. 2019. Liberty and Justice for All. In Religious Freedom, LGBT Rights, and the Prospects for Common Ground. Edited by William N. Eskridge Jr. and Robin Fretwell Wilson. Cambridge: Cambridge University Press, pp. 24-37.

Leavitt, Governor Michael O. 2019. Shared Spaces and Brave Gambles. In Religious Freedom, LGBT Rights, and the Prospects for Common Ground. Edited by William N. Eskridge Jr. and Robin Fretwell Wilson. Cambridge: Cambridge University Press, pp. 460-76.

LeDrew, Stephen. 2020. Atheism as a Political Project: Review Essay. Politics and Religion 13: 415-23. [CrossRef] Lieb, David A. 2017. FEMA Rethinking Ban on Disaster Aid for Churches. New York Times, November 12, A5. 
Liptak, Adam. 2020. Justices to Hear Case of Agency with Foster Care Policy That Excludes Gay Couples. New York Times, February 25, A15.

Locke, John. 1983. A Letter Concerning Toleration. Edited by James H. Tully. Indianapolis: Hackett Publishing Company. First published 1689.

Lupu, Ira C., and Robert W. Tuttle. 2014. Secular Government, Religious People. Grand Rapids: William B. Eerdmans. Lupu, Ira C., and Robert W. Tuttle. 2016. Religious Exercise and the Limited Relevance of Corporate Identity. In The Rise of Corporate Religious Liberty. Edited by Micah Schwartzman, Chad Flanders and Zoë Robinson. New York: Oxford University Press, pp. 373-97.

Marcus, Benjamin P. 2020. Knowledge is Power. Church \& State 73: 18-19.

McClain, Linda C. 2019. The Rhetoric of Bigotry and Conscience in Battles over 'Religious Liberty v. LGBT Rights'. In Religious Freedom, LGBT Rights, and the Prospects for Common Ground. Edited by William N. Eskridge Jr. and Robin Fretwell Wilson. Cambridge: Cambridge University Press, pp. 213-32.

McConnell, Michael W. 2020. The Court Protects the Right to be Different. New York Times, July 10, A25.

Melling, Louise. 2019. Heterosexuals Only: Signs of the Times? In Religious Freedom, LGBT Rights, and the Prospects for Common Ground. Edited by William N. Eskridge Jr. and Robin Fretwell Wilson. Cambridge: Cambridge University Press, pp. 245-55.

Monsma, Steven V. 1996. When Sacred and Secular Mix: Religious Nonprofit Organizations and Public Money. Lanham: Rowman \& Littlefield.

Murphy, Andrew R. 2001. Conscience and Community: Revisiting Toleration and Religious Dissent in Early Modern England and America. University Park: Pennsylvania State University Press.

Neal, Patrick. 1997. Liberalism and Its Discontents. New York: New York University Press.

NeJaime, Douglas, and Reva B. Siegel. 2019. Religious Accommodation, and Its Limits, in a Pluralist Society. In Religious Freedom, LGBT Rights, and the Prospects for Common Ground. Edited by William N. Eskridge Jr. and Robin Fretwell Wilson. Cambridge: Cambridge University Press, pp. 69-81.

Nussbaum, Martha C. 2000. Religion and Women's Equality: The Case of India. In Obligations of Citizenship and Demands of Faith: Religious Accommodation in Pluralist Democracies. Edited by Nancy L. Rosenblum. Princeton: Princeton University Press, pp. 335-402.

Nussbaum, Martha C. 2008. Liberty of Conscience: In Defense of America's Tradition of Religious Liberty. New York: Basic Books.

Patten, Alan. 2014. Equal Recognition: The Moral Foundations of Minority Rights. Princeton: Princeton University Press.

Pear, Robert, and Rebecca R. Ruiz. 2017. Trump Relaxes Employers' Duty on Birth Control. New York Times, October 7, A1, A14.

Perry, Michael J. 2019. Conscience v. Access and the Morality of Human Rights, with Particular Reference to Same-Sex Marriage. In Religious Liberty, LGBT Rights, and the Prospects for Common Ground. Edited by William N. Eskridge Jr. and Robin Fretwell Wilson. Cambridge: Cambridge University Press, pp. 256-66.

Politico. 2019. September 3. Available online: https://www.politico.com/ (accessed on 14 September 2020).

Pollman, Elizabeth. 2016. Corporate Law and Theory in Hobby Lobby. In The Rise of Corporate Religious Liberty. Edited by Micah Schwartzman, Chad Flanders and Zoë Robinson. New York: Oxford University Press, pp. 149-71.

Renkl, Margaret. 2019. How to Stand Up to the Catholic Church. New York Times, July 2, A19.

Richards, David A. J. 1999. Identity and the Case for Gay Rights: Race, Gender, and Religion as Analogies. Chicago: University of Chicago Press.

Robinson, Zoë. 2016. Hosanna-Tabor after Hobby Lobby. In The Rise of Corporate Religious Liberty. Edited by Micah Schwartzman, Chad Flanders and Zoë Robinson. New York: Oxford University Press, pp. 173-91.

Rogers, Melissa. 2005. Federal Funding and Religion-Based Employment Decisions. In Sanctioning Religion? Politics, Law, and Faith-Based Public Services. Edited by David K. Ryden and Jeffrey Polet. Boulder: Lynne Rienner, pp. 105-24.

Rogers, Melissa. 2019. Faith in American Public Life. Waco: Baylor University Press.

Rosenblum, Nancy L. 1998. Membership and Morals: The Personal Uses of Pluralism in America. Princeton: Princeton University Press.

Rosenblum, Nancy L. 2000. Introduction: Pluralism, Integralism, and Political Theories of Religious Accommodation. In Obligations of Citizenship and Demands of Faith: Religious Accommodation in Pluralist Democracies. Edited by Nancy L. Rosenblum. Princeton: Princeton University Press, pp. 3-31. 
Russell-Kraft, Stephanie. 2016. Rise of Zombie Hospitals. New Republic 247: 12-13.

Sager, Lawrence. 2016. Why, Churches (and, Possibly, the Tarpon Bay Women's Blue Water Fishing Club) Can Discriminate. In The Rise of Corporate Religious Liberty. Edited by Micah Schwartzman, Chad Flanders and Zoë Robinson. New York: Oxford University Press, pp. 77-101.

Sanger-Katz, Margot, and Noah Weiland. 2020. White House Eliminates Transgender Civil Rights Protections in Medical Care. New York Times, June 13, A17.

Sepper, Elizabeth. 2016. Heathcare Exemptions and the Future of Corporate Religious Liberty. In The Rise of Corporate Religious Liberty. Edited by Micah Schwartzman, Chad Robinson and Zoë Robinson. New York: Oxford University Press, pp. 305-22.

Smith, Steven D. 2016. The Jurisdictional Conception of Church Autonomy. In The Rise of Corporate Religious Liberty. Edited by Micah Schwartzman, Chad Flanders and Zoë Robinson. New York: Oxford University Press, pp. 19-37.

Smith, Steven D. 2019. Against 'Civil Rights' Simplism: How Not to Accommodate Competing Legal Commitments. In Religious Freedom, LGBT Rights, and the Prospects for Common Ground. Edited by William N. Eskridge Jr. and Robin Fretwell Wilson. Cambridge: Cambridge University Press, pp. 233-44.

Stack, Liam, and Sheri Fink. 2020. Evangelical Leader Closing Central Park Field Hospital. New York Times, May 11, A17.

Stewart, Katherine. 2019. The Power Worshippers: Inside the Dangerous Rise of Religious Nationalism. New York: Bloomsbury Publishing.

Taylor, Derrick Bryson. 2019. Jesuit School, Defying Archdiocese, Refuses to Fire Teacher in Gay Marriage. New York Times, June 22, A13.

Tebbe, Nelson. 2017. Religious Freedom in an Egalitarian Age. Cambridge: Harvard University Press.

Verma, Pranshu. 2020a. Pompeo Panel Threatens Human Rights, Critics Say. New York Times, June 24, A18.

Verma, Pranshu. 2020b. Pompeo Says Human rights Must Reflect Religion's Role. New York Times, July 17, A19.

Verma, Pranshu. 2020c. Allies Skeptical of U.S. Push to Redefine Human Rights. New York Times, September 23, A9.

Walsh, Mary Williams. 2006. Pensions in Peril Over Exemption Tied to Churches. New York Times, May 2, A1, C6.

Warbelow, Sarah. 2019. Sound Nondiscrimination Models and the Need to Protet LGBTQ People in Federal Law. In Religious Liberty, LGBT Rights, and the Prospects for Common Ground. Edited by William N. Eskridge Jr. and Robin Fretwell Wilson. Cambridge: Cambridge University Press, pp. 423-40.

West, Robin. 2016. Freedom of the Church and Our Endangered Civil Rights: Exiting the Social Contract. In The Rise of Corporate Religious Liberty. Edited by Micah Schwartzman, Chad Flanders and Zoë Robinson. New York: Oxford University Press, pp. 399-418.

Wexler, Jay. 2019. Our Non-Christian Nation: How Atheists, Satanists, Pagans, and Others Are Demanding Their Rightful Place in Public Life. Stanford: Redwood Press of Stanford University Press.

Wilson, Robin Fretwell. 2008. Matters of Conscience: Lessons for Same-Sex Marriage from the Heathcare Context. In Same-Sex Marriage and Religious Liberty: Emerging Conflicts. Edited by Douglas Laycock, Anthony R. Picarello Jr. and Robin Fretwell Wilson. Lanham: Becket Fund for Religious Liberty and Rowman \& Littlefield, pp. 76-102.

Wilson, Robin Fretwell. 2016. Bargaining for Religious Accommodations. In The Rise of Corporate Religious Liberty. Edited by Micah Schwartzman, Chad Flanders and Zoë Robinson. New York: Oxford University Press, pp. 257-83.

Wilson, Robin Fretwell. 2019. Bathrooms and Bakers: How Sharing the Public Square Is the Key to a Truce in the Culture Wars. In Religious Freedom, LGBT Rights, and the Prospects for Common Ground. Edited by William N. Eskridge Jr. and Robin Fretwell Wilson. Cambridge: Cambridge University Press, pp. 402-20.

Publisher's Note: MDPI stays neutral with regard to jurisdictional claims in published maps and institutional affiliations.

(C) 2020 by the author. Licensee MDPI, Basel, Switzerland. This article is an open access article distributed under the terms and conditions of the Creative Commons Attribution (CC BY) license (http://creativecommons.org/licenses/by/4.0/). 